\title{
ARTHUR ANDERSEN AND THE MYTH OF THE Corporate Death Penalty: Corporate CRIMINAL CONVICTIONS IN THE TWENTY-FIRST Century
}

\author{
Gabriel Markoff*
}

\begin{abstract}
The conventional wisdom states that prosecuting corporations can subject them to terrible collateral consequences that risk putting them out of business and causing massive social and economic harm. According to this viewpoint, which has come to dominate the literature following the demise of Arthur Andersen after that firm's prosecution in the wake of the Enron scandal, even a criminal indictment can be a "corporate death penalty." The Department of Justice (DOJ) has implicitly accepted this view by declining to prosecute many large companies in favor of using criminal settlements called deferred prosecution agreements (DPAs). Yet, there is no evidence to support the existence of the "Andersen Effect" and the much-hyped corporate death penalty. Indeed, no one has ever empirically studied what happens to companies after conviction. In this Article, I do just that. Using the database of organizational convictions made publicly available by Professor Brandon Garrett, I find that no
\end{abstract}

\footnotetext{
* Law Clerk to the Honorable Gregg Costa, United States District Judge for the Southern District of Texas (2012-2013). J.D., Class of 2012, The University of Texas School of Law. All views and opinions expressed within are my own and should not be taken to reflect the position of any other individual or entity. I wish to extend my thanks to Barry McNeil and Stacy Brainin, for their invaluable instruction; to Brandon Garrett, for his advice, freely given, and his extraordinary dataset, generously shared; to Mike Koehler, for his assistance in navigating the submissions process; and to the Honorable Gregg Costa, for his encouragement and guidance. To Tansy Woan and the staff of the University of Pennsylvania Journal of Business Law, I thank you for your excellent work. Thanks go also to Keith Cohan, Monica Gaudioso, Alex Hughes, Lisa Kinzer, Nicole LeFave, Josh Packman, George Padis, Drew Pennebaker, Jeff Quilici, Sean Thompson, Kate Wagner, Colin Watterson, and Eric Werlinger, who know what they did. Finally, to Ein: All my love.
} 
publicly traded company failed because of a conviction that occurred in the years 2001 to 2010. Moreover, many convictions included plea agreements that imposed compliance programs such as those that some advocates view as a key justification for using DPAs. Because corporate convictions do not have the terrible consequences they were assumed to have and because convictions can be used to obtain compliance programs just as effectively as DPAs can, the DOJ should prosecute more law-breaking companies and reserve DPAs for extraordinary circumstances. In the absence of some other justification for using DPAs, the DOJ should exploit the stronger deterrent value of corporation prosecution to its full capacity.

\section{TABLE OF CONTENTS}

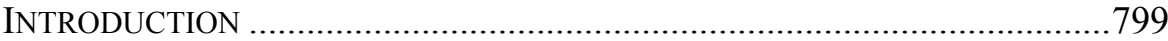

I.AN OVERVIEW OF CORPORATE CRIMINAL LIABILITY ............................802

A. Corporate Criminal Liability Pre-Andersen ............................802

B. The Collapse of Arthur Andersen and the Move Toward DPAs.

C. Where We Stand Today: The Controversies of the Modern

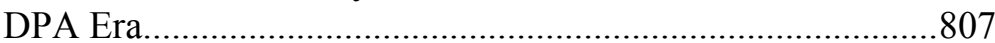

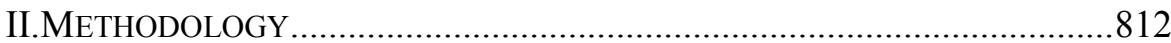

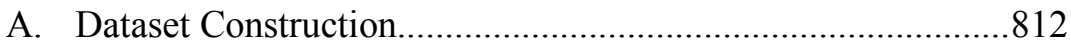

B. Conviction Data and Fate After Conviction .............................814

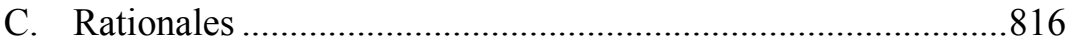

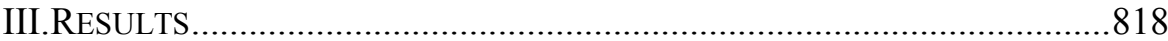

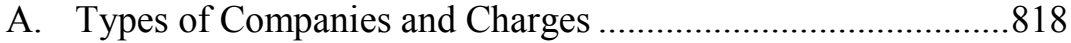

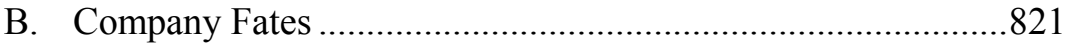

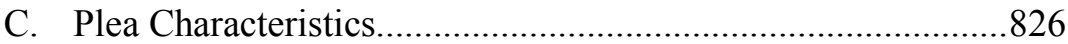

D. Implications: No Evidence of an Andersen Effect ...................827

E. Implications: Structural Reforms May Be Obtained

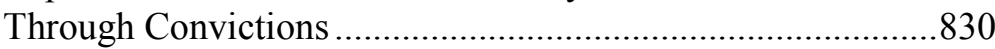

IV.OUTLINING A "CORE BUSINESS MODEL" OF CORPORATE

CRIMINAL PROSECUTIONS ……...................................................... 831

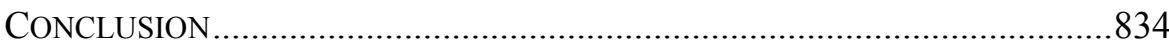




\section{INTRODUCTION}

The beginning of the twenty-first century has seen the dawning of a new era of criminality. This new era has been planned and perpetuated not by such traditional criminal players as organized crime or drug cartels, but instead by the large, multinational corporations that are essential actors in both the economy and society at large. Since the Enron scandal burst open in late 2001, marking the beginning of a decade of fraud and wrongdoing that culminated in the recent financial crisis, the criminal acts of large corporations have rocked the nation and brought the world economy to its knees. It is no exaggeration to say that corporate crime, and the struggle to counteract it, has become one of the most pressing legal issues of the new millennium.

Under current law, there are a number of ways to combat corporate crime. Corporations can be prosecuted to impose punitive fines and the stigma of conviction, corporate officers can be prosecuted to ensure that individuals who break the law on behalf of their corporations are punished, structural reforms and compliance programs may be implemented through the use of deferred and non-prosecution agreements, and the entire body of civil and regulatory law can be used to impose fines and win compensation for victims. ${ }^{1}$ Each of these methods has its proponents and detractors. In this Article, I provide novel empirical evidence to demonstrate that the first of these methods, the criminal prosecution of the corporate entity itself, has been fundamentally misunderstood by scholars, commentators, and policymakers.

While the fact that corporations cannot be imprisoned has long been recognized as an inherent incongruity of corporate criminal liability, ${ }^{2}$ most commentators believe that corporate prosecutions play an important role in deterring corporate crime. ${ }^{3}$ That said, there is a broad consensus - and a

1. Brandon L. Garrett, Structural Reform Prosecution, 93 VA. L. REV. 853, 875-86 (2007) [hereinafter Garrett, Structural Reform] (reviewing alternative means of combating corporate crime)

2. See, e.g., John C. Coffee, Jr., "No Soul to Damn: No Body to Kick": An Unscandalized Inquiry into the Problem of Corporate Punishment, 79 MicH. L. REV. 386, 389-90 (1981) (discussing the deterrent value of corporate prosecutions for intangible entities).

3. See Assaf Hamdani \& Alon Klement, Corporate Crime and Deterrence, 61 STAN. L. REV. 271, 273-74 (2008) (noting that the consensus among scholars favors some measure of corporate criminal liability). This belief is not universal, however. A prominent voice against corporate criminal liability is that of Professor Richard Epstein, a leading member of the law and economics movement. See Richard A. Epstein, The Deferred Prosecution Racket, Wall St. J., Nov. 28, 2006, at A14 (arguing that the government should limit 
deep fear - that the stigma and side effects of corporate prosecutions can be so damaging that they pose a severe risk of driving companies out of business. Therefore, many believe that prosecutions should be limited to avoid this result. ${ }^{4}$ The belief that prosecutions are a "corporate death penalty" was amplified immeasurably by the collapse of Arthur Andersen LLP, Enron's accountant, after Arthur Andersen was convicted of obstruction of justice for destroying tons of potentially incriminating documents in the days leading up to Enron's implosion. ${ }^{5}$ For many commentators, it is now unquestioned dogma that a criminal indictment alone can easily destroy even a large, powerful corporation. ${ }^{6}$

In large part because of the backlash caused by Andersen's demise, the DOJ has shifted its approach to enforcing the criminal law against large corporations. ${ }^{7}$ While small companies are still routinely convicted, usually through plea agreement though sometimes by trial verdict, many large corporations are not actually prosecuted; instead they receive settlements known as deferred or non-prosecution agreements (collectively, DPAs). ${ }^{8}$ These DPAs are, for all intents and purposes, criminal settlement agreements by which companies agree to cooperate with the government, admit some level of wrongdoing, pay fines and restitution, implement compliance programs, and undertake other reforms, all in exchange for the government's agreeing to not prosecute the corporation. ${ }^{9}$ In theory, these arrangements are mutually beneficial: DPAs supposedly allow the DOJ to efficiently enforce the law and obtain monetary restitution for victims while also permitting companies to avoid criminal conviction and the resulting "Arthur Andersen Effect," that is, the expense, stigma, and other collateral consequences that accompany a criminal conviction.

DPAs themselves are highly controversial in many respects. Criticism of these agreements runs the gamut. Some scholars, particularly members

criminal law enforcement to suits against individuals).

4. See Hamdani \& Klement, supra note 3, at 274 ("Yet, the prevailing view is that prosecutors should balance the need to deter corporate crime against a conviction's dire consequences for employees and other innocent stakeholders.").

5. See Kathleen F. Brickey, Andersen's Fall from Grace, 81 WASH. U. L.Q. 917, 929 34 (2004) (describing Andersen's destruction of Enron documents).

6. See infra notes 40-41 and accompanying text (listing scholars who argue that criminal indictments can destroy even the most established companies). Andersen itself, of course, was a professional services partnership and not a corporation, but this important fact is often ignored by commentators.

7. Garrett, Structural Reform, supra note 1, at 880, 887-89.

8. Id.

9. Lisa Kern Griffin, Compelled Cooperation and the New Corporate Criminal Procedure, 82 N.Y.U. L. REV. 311, 321-22 (2007). 
of the law and economics movement, argue that DPAs can often constitute extreme abuses of prosecutorial discretion. ${ }^{10}$ Other scholars decry DPAs as a means of letting corporate criminals escape with a slap on the wrist. ${ }^{11}$ And others advocate for specific reforms while accepting DPAs as a legitimate tool. ${ }^{12}$ Unfortunately, in spite of the great volume of commentary on the matter, there is little to no empirical proof that DPAs are effective at deterring or otherwise preventing corporate crime, and there is anecdotal evidence of DPAs failing spectacularly at preventing corporate recidivism. While a few scholars have performed invaluable empirical studies of DPAs by laboriously gathering them and documenting their attributes, ${ }^{13}$ the question of whether DPAs "work" has not been answered. ${ }^{14}$

I attempt to answer a different question, one that has been almost entirely ignored in the literature. The question that should be asked, from the policymaker's perspective, is not whether DPAs "work," but whether DPAs work better than actual corporate prosecutions and convictions. As is generally recognized in the literature, prosecutions have a stronger deterrent effect than do DPAs, which typically lack the stigma and potential collateral consequences that accompany convictions. Therefore, because their deterrent value is weaker, the use of DPAs can only be justified if DPAs provide some other advantage that prosecutions lack. Recognizing this problem, DPA advocates generally cite two purported advantages to justify the use of DPAs. The first, as already mentioned, is that corporate prosecutions cannot be used in many cases because they risk causing huge social costs, such as massive job losses, by dooming companies to the fate of Arthur Andersen. The second is that DPAs can be used to force corporations to voluntarily agree to valuable structural reforms and compliance programs that are unavailable in the adversarial

10. See, e.g., Epstein, supra note 3 (arguing that the government is abusing the threat of prosecution in order to unfairly coerce corporations into DPAs).

11. See Brandon L. Garrett, Globalized Corporate Prosecutions, 97 VA. L. REV. 1775, 1795 (2011) [hereinafter Garrett, Globalized Corporate Prosecutions] (noting that some advocates condemn the trend away from corporate prosecutions).

12. See, e.g., Michael L. Seigel, Corporate America Fights Back: The Battle Over Waiver of the Attorney-Client Privilege, 49 B.C. L. REv. 1, 54 (2008) (arguing that prosecutors should continue to have the power to demand that corporations waive the attorney-client privilege as a condition of receiving DPAs, but that additional protections should be added to protect individuals' rights against self-incrimination).

13. See, e.g., Garrett, Structural Reform, supra note 1 (analyzing the characteristics of thirty-five DPAs entered into between 2003 and 2007).

14. This is not to say that nobody has tried to do so. See, e.g., Cristie Ford \& David Hess, Can Corporate Monitorships Improve Corporate Compliance?, 34 J. CORP. L. 679 (2009) (using targeted interviews to attempt to draw anecdotal evidence of the success or failure of corporate monitors put in place as part of DPAs). 
setting of a prosecution.

This Article presents novel evidence that DPAs possess neither of these proposed advantages. The Article surveys every available federal conviction of a publicly traded company that occurred in the years between 2001 and 2010, inclusive, and concludes that the risk of driving companies out of business through prosecutions has been radically exaggerated, and that prosecutions can indeed be used to obtain structural reforms. When viewed in light of the empirical evidence, the DOJ's policy of preferring DPAs is unsupportable. The Article proceeds in the following manner. Part I discusses the background of corporate criminal liability and the government's trend toward using DPAs. Part II discusses the methodology used in analyzing the available data and explains how the survey was conducted and the results were obtained. Part III lays out the results of the study and discusses some of the implications of these results. Finally, Part IV makes a normative prescription: In most cases, the use of DPAs should be phased out in favor of pursuing corporate criminal convictions. Because the risk of driving large companies out of business through prosecution is far less than the conventional wisdom assumes-and is perhaps even negligible - and because convictions can also be used to obtain structural reforms, then, in the absence of some other justification for the use of DPAs, the use of corporate convictions should be favored because of their naturally stronger deterrent value.

\section{AN OVERVIEW OF CORPORATE CRIMINAL LIABILITY}

\section{A. Corporate Criminal Liability Pre-Andersen}

In the United States, corporations have long been held liable for the criminal acts of their employees. The traditional common law rule that corporations could not be held criminally liable for most acts had largely vanished by the early twentieth century. ${ }^{15}$ As early as 1909, the U.S. Supreme Court held that corporations could be criminally liable for crimes of intent that were committed by their employees. ${ }^{16}$ Since then, the doctrine of respondeat superior has allowed corporations to be convicted for the criminal acts of their employees so long as those acts were made in

15. See V.S. Khanna, Corporate Criminal Liability: What Purpose Does it Serve?, 109 HARV. L. REV. 1477, 1479-83 (1996) (discussing the historical development of corporate criminal liability from sixteenth-century English law to twentieth-century American law).

16. N.Y. Cent. \& Hudson River R.R. v. United States, 212 U.S. 481, 494-95 (1909); Khanna, supra note 15 , at 1482-83. 
the scope of employment and with the intent of benefitting the corporation. ${ }^{17}$ The doctrine is broadly applicable, and corporations have been held liable for almost all types of crimes, with the exception of crimes like murder or rape, which in many jurisdictions require a particular type of malicious intent on the part of the wrongdoer. ${ }^{18}$

Even so, until the 1990 s, corporate prosecutions were a minor part of American law. Before that time, prosecutions occurred but fines were very small, much smaller than the penalties imposed by the administrative actions and private lawsuits that inevitably arise as a result of corporate law-breaking. ${ }^{19}$ Things began to change with the passage of the Sentencing Reform Act in 1984, which established the U.S. Sentencing Commission and, ultimately, the federal Sentencing Guidelines. ${ }^{20}$ In light of evidence that organizations were, on average, receiving criminal fines that did not even rise to the level of the damage their crimes caused, the Commission determined to create guidelines that would follow a modified version of the "optimal deterrence" school of law and economics thought. ${ }^{21}$ In the end, the guidelines radically increased penalties for corporate criminal liability while also allowing reduced punishments and incentives for good faith cooperation by corporate defendants. ${ }^{22}$

Armed with the power to seek larger, more punitive fines, the DOJ began to ramp up corporate prosecutions during the 1990s. ${ }^{23}$ This development was legally strengthened in 1999, when then-Deputy Attorney General Eric Holder drafted the first set of DOJ guidelines to provide instructions on how federal prosecutors were to prosecute corporations. ${ }^{24}$

17. Hamdani \& Klement, supra note 3, at 277, 295.

18. This limitation has been long noted. See Henry W. Edgerton, Corporate Criminal Responsibility, 36 YALE L. J. 827, 828-29 (1927) (listing court decisions holding that corporations could not be held liable for crimes involving a conspicuous element of mens rea); Khanna, supra note 15, at 1484 (noting the longstanding acceptance of this limitation).

19. See Coffee, supra note 2, at 388, 405-06 (noting that criminal fines for corporate crime were "insignificant" before 1980, and describing in detail the relatively tiny fines imposed for criminal antitrust violations).

20. Sentencing Reform Act of 1984, Pub. L. No. 98-473, 98 Stat. 1987 (1984). See Ilene M. Nagel \& Winthrop M. Swenson, The Federal Sentencing Guidelines for Corporations: Their Development, Theoretical Underpinnings, and Some Thoughts About Their Future, 71 WASH. U. L.Q. 205, 206-08 (1993) (describing the passage of the Sentencing Reform Act and the Commission's work on drafting guidelines for organizational sentences).

21. Nagel \& Winthrop, supra note 20, at 214-22.

22. Id.

23. See Garrett, Globalized Corporate Prosecutions, supra note 11, at 1870 (stating that the number of corporate convictions rose through the 1990s, but cautioning that some of the rise might be due to better data collection).

24. Dane C. Ball \& Daniel E. Bolia, Ending a Decade of Federal Prosecutorial Abuse 
This "Holder Memo," as it became known, advised prosecutors to base charging decisions against corporations on the same factors used in prosecuting individuals, such as the sufficiency of the evidence, the likelihood of success at trial, and the deterrent value of prosecution. ${ }^{25}$ However, the Holder Memo supplemented these factors with eight additional factors unique to organizational prosecutions: (1) "the nature and seriousness of the offense"; (2) the "pervasiveness of wrongdoing within the corporation"; (3) the corporation's history of past criminal conduct; (4) the corporation's timely disclosure and willingness to cooperate; (5) the adequacy of the corporation's compliance program; (6) the remedial actions the corporation had undertaken; (7) the collateral consequences of prosecution to innocent shareholders and employees; and (8) the "adequacy of non-criminal remedies." 26

In 2000, the year after the Holder Memo was issued, the number of corporate convictions reached an all-time high of approximately $300 .^{27}$ The Holder Memo has since been superseded by other DOJ guidance documents, but the factors it outlined remain the basic framework on which charging decisions are made. However, the politics of corporate criminal prosecution were to change dramatically only three years after the memo was published, even though the law itself did not change. The catalyst for this shift was the dramatic downfall of Arthur Andersen.

\section{B. The Collapse of Arthur Andersen and the Move Toward DPAs}

Arthur Andersen LLP, formerly one of the "big five" accounting firms, was the outside accountant of Enron Corporation. ${ }^{28}$ In that role, Andersen was at least negligent of - and many commentators believe complicit with - the fraudulent accounting schemes that contributed to Enron's downfall. ${ }^{29}$ And, as Enron entered its death throes in the weeks leading up to its bankruptcy filing in late 2001, high-ranking Andersen partner David Duncan, the leader of Andersen's Enron account, ordered

in the Corporate Criminal Charging Decision, 9 Wyo. L. REv. 229, 239 (2009).

25. Memorandum from the Deputy Att'y Gen. to the Component Heads \& U.S. Attorneys, Bringing Criminal Charges Against Corps. (June 16, 1999) [hereinafter Holder Memo], available at http://federalevidence.com/corporate-prosecution-principles.

26. Id.

27. Garrett, Globalized Corporate Prosecutions, supra note 11, at 1870.

28. Brickey, supra note 5, at 917.

29. See Bethany McLean \& Peter Elkind, The Smartest Guys in the Room: The Amazing Rise AND Scandalous Fall of ENRON 143-49 (2003) (describing Andersen's failure to challenge Enron's questionable and ultimately fraudulent accounting practices). 
Andersen employees to destroy enormous quantities of Enron documents. ${ }^{30}$ While the shredding eventually stopped in early November 2001, after the Securities and Exchange Commission (SEC) subpoenaed Andersen, the firm had by that time already destroyed literally tons of documents that could have provided evidence of Enron's wrongdoing and of Andersen's own complicity. ${ }^{31}$

Andersen publicly admitted the document destruction in January 2002. ${ }^{32}$ At that point, its major clients began fleeing in droves, and Andersen began negotiating with the government to avoid criminal prosecution. ${ }^{33}$ Avoiding prosecution without admitting guilt was crucial to the firm's chances of survival because Andersen had previously admitted to its involvement in numerous other fraudulent schemes. Indeed, it had settled criminal charges in 1996 by agreeing to a DPA, and, just months before the Enron debacle, the SEC had censured Andersen as part of a settlement permanently enjoining the firm from violating the federal securities laws. ${ }^{34}$ If Andersen admitted its fault, it would have further damaged its reputation, and a conviction would likely have resulted - as it ultimately did - in the SEC's disbarring Andersen from auditing public companies. Therefore, Andersen was desperate to avoid admitting to wrongdoing. ${ }^{35}$ To that end, it offered to enter into a DPA, to follow a new compliance program, and to have an independent monitor appointed to ensure that it followed the law. ${ }^{36}$ However, it refused to admit wrongdoing even as part of a DPA that would allow it to avoid conviction, and the DOJ quite reasonably would not agree to such an extravagant demand. ${ }^{37}$ Andersen was indicted in March 2002, and its business crumbled in the time leading up to its conviction that June. ${ }^{38}$

The backlash against the government's actions was immediate. Andersen's defense strategy had revolved heavily on a public relations

30. Brickey, supra note 5, at 929-34.

31. MCLEAN \& ELKIND, supra note 29, at 383.

32. Brickey, supra note 5, at 920.

33. Id. at $924-25,951$.

34. Id. at $922-27$.

35. Id. at $921,924-26$

36. Id. at $921,924-26$.

37. Id. at $924-26$.

38. Andersen's conviction was ultimately overturned by the Supreme Court because of error in the jury instructions. Arthur Andersen LLP v. United States, 544 U.S. 696, 698 (2005). Though the reversal did not damage the government's factual case, and a retrial would likely have been successful, the DOJ decided not to retry the case on remand, as the business was already long defunct. John C. Roper et al., Government won't retry Anderson criminal case, HOUS. CHRON., Nov. 23, 2005, at B1. 
campaign that tried the case in the popular press; even while the trial was ongoing, the firm loudly decried the prosecution's actions as a witch hunt. ${ }^{39}$ While the attack on the DOJ did not help Andersen, the idea that corporate prosecutions are unjustifiably dangerous has lived on and dominates academic discussions of corporate wrongdoing. Andersen's collapse, many commentators argue, showed that a mere indictment can destroy even a huge, established company by causing extreme reputational damage and by triggering other collateral consequences, such as disbarment, exclusion from government contracts, or the activation of loan covenants that raise the cost of borrowing. ${ }^{40}$ Some commentators even veer into the hyperbolic and go so far as to make such claims as the following: "Indictment alone, prior to any litigation, usually results in the death of any business entity by means of reputational damage in the marketplace and damage to the financial interests of its shareholders and investors." 41

Following this torrid criticism, the DOJ changed its tactics. While small companies are usually still convicted (either by guilty verdict after a trial or by plea agreement), the DOJ has embraced the use of DPAs as an

39. See Brickey, supra note 5, at 942-45 (describing Andersen's public relations campaign, which involved employee protests, newspaper advertisements, grassroots lobbying of Congress and the DOJ by employees, and a website that hosted papers claiming that the prosecution was legally flawed and an abuse of the government's power).

40. See, e.g., Andrew Weissmann \& David Newman, Rethinking Corporate Criminal Liability, 82 IND. L.J. 411, 426 (2007) ("A criminal indictment can have devastating consequences for a corporation and risks the market imposing what is in effect a corporate death penalty."); Erik Paulsen, Note, Imposing Limits on Prosecutorial Discretion in Corporate Prosecution Agreements, 82 N.Y.U. L. REV. 1434, 1436 (2007) ("When Andersen collapsed after its indictment, federal prosecutors realized that prosecution alone could destroy even the most established of companies."); Joseph A. Grundfest, Op-Ed., Over Before it Started, N.Y. Times, June 14, 2005, at A23 ("But Andersen's demise did serve as a stern reminder to corporate America that prosecutors can bring down or cripple many of America's leading corporations simply by indicting them on sufficiently serious charges. No trial is necessary."); see also, e.g., James Kelly, The Power of an Indictment and the Demise of Arthur Andersen, 48 S. TEX. L. REV. 509, 511 (2006) ("In short, the United States Government has the power to destroy a partnership, such as an accounting or law firm, without the burden of trial or having to provide evidence of a crime beyond a reasonable doubt."). Notably, the fact that Andersen was a partnership, a form of the corporate entity that is often more fragile than that of a corporation or limited liability company, is only rarely mentioned.

41. Matt Senko, Note, Prosecutorial Overreaching in Deferred Prosecution Agreements, 19 S. CAL. INTERDISC. L.J. 163, 164 (2009) (emphasis added); see also Edward B. Diskant, Note, Comparative Corporate Criminal Liability: Exploring the Uniquely American Doctrine Through Comparative Criminal Procedure, 118 YALE L.J. 126, 128-29 (2008) (" $\mathrm{I}] \mathrm{t}$ is common wisdom within the business community that a conviction amounts to a potentially lethal blow for a corporation, one from which the corporation may not recover even if it is actually innocent...."). 
alternative means of enforcing the criminal law against many large companies, particularly publicly traded corporations. ${ }^{42}$ As already mentioned, by using DPAs, the DOJ avoids the potential collateral consequences of indictment and conviction while obtaining structural reforms and the corporation's aid in prosecuting individual corporate officers. In exchange, the DOJ gives up the increased deterrent effect of actually prosecuting the corporation itself. Pursuant to this new strategy, corporate convictions have declined from a high of 300 in the year 2000 to an average of less than 200 (mostly small) convicted organizations per year for the years 2001-2010, with only 145 organizations convicted in $2010 .^{43}$ By contrast, the number of DPAs has climbed steadily, from a handful per year before Andersen to an average of approximately 30 per year, the vast bulk of which are entered into by large, multinational corporations. ${ }^{44}$

\section{Where We Stand Today: The Controversies of the Modern DPA Era}

DPAs are enjoying their time in the sun, their use bolstered by a continued belief in the devastating power of the Andersen Effect. ${ }^{45}$ Indeed, at the same time this Article was being submitted for publication, former Assistant Attorney General Lanny Breuer, until recently the head of the DOJ's Criminal Division, extolled the virtues of DPAs in a now-famous speech to the New York City Bar Association. ${ }^{46}$ Breuer noted that "DPAs have become a mainstay of white collar criminal law enforcement" and praised them as having "a truly transformative effect on particular companies and, more generally, on corporate culture across the globe." ${ }^{, 47}$ In

42. Griffin, supra note 9, at 321-22; see Garrett, Globalized Corporate Prosecutions, supra note 11, at 1804 (noting that most corporations that are convicted are relatively small). Indeed, as I found while conducting this study, large, public corporations receive DPAs almost twice as often as they are convicted. In the years 2001-2010, eighty-nine publicly traded companies received DPAs while there were only fifty-four convictions of publicly traded companies. Data on file with Author.

43. Garrett, Globalized Corporate Prosecutions, supra note 11, at 1804, 1870; infra notes $57-58$ and accompanying text.

44. Id. at $1794,1871$.

45. See generally Gretchen Morgenson \& Louise Story, Behind the Gentler Approach to Banks by U.S., N.Y. TIMES, July 7, 2011, at A1 (discussing the rise of DPAs and summarizing common criticisms of their use).

46. Lanny A. Breuer, U.S. Dep't of Justice, Address at the New York City Bar Association (Sept. 13, 2012), available at http://www.justice.gov/criminal/pr/speeches/2 012/crm-speech-1209131.html.

47. Id. 
particular, Breuer spoke at length of the dangers of potential collateral consequences of conviction (i.e., the Andersen Effect) and, controversially, lauded DPAs for giving the government leverage to obtain settlements in situations where prosecutors previously had "faced a stark choice when they encountered a corporation that had engaged in misconduct-either indict, or walk away." 48

But while DPAs are in vogue at the DOJ, they have been fiercely criticized elsewhere. In fact, the settlement leverage that Breuer praised is extraordinarily controversial among academics and the corporate defense bar. Professor Mike Koehler, a leading expert on the Foreign Corrupt Practices Act, responded to Breuer's negative view of the "stark choice" between indictment and declining to prosecute by stating:

There is absolutely, positively nothing wrong with this choice. Bringing criminal charges against [a] person (natural or legal) should not be easy. It should be difficult. Our founding fathers recognized this as a necessary bulwark against an all powerful government. There is no legal or policy reason warranting a change from such a fundamental and long-lasting principle. ${ }^{49}$

Similarly, many other commentators accuse the DOJ of abusing its prosecutorial discretion by conditioning DPAs on demands for expensive compliance programs and, in particular, by requesting that corporations waive their attorney-client privilege as part of the agreements so that the DOJ may use privileged corporate documents to prosecute individual corporate officers. $^{50}$ Typically, these commentators argue that corporations, fearful of the grave danger of being driven out of business and suffering the same fate as Arthur Andersen, have no choice but to buckle and agree to whatever demands the DOJ makes, no matter how ruthless, unfair, or coercive. ${ }^{51}$ This argument is exemplified by a column

48. Id.

49. Mike Koehler, Assistant Attorney General Breuer's Unconvincing Defense of DPAs/NPAs, FCPA Professor (Sept. 17, 2012), http://www.fcpaprofessor.com/assistantattorney-general-breuers-unconvincing-defense-of-dpas-npas.

50. See Seigel, supra note 12, at 4-5 (detailing the corporate backlash against DPAs).

51. See, e.g., Griffin, supra note 9, at 327 ("Because virtually no company will risk indictment, prosecutors have come to expect compliance with every government demand."); Paulsen, supra note 40, at 1457 ("The legal and reputational vulnerabilities detailed above make corporations uniquely weak negotiators in the criminal context. Since corporations cannot run the risk of going to trial, their choice to accept a deferred prosecution agreement is not really a choice at all."); see also Weissmann \& Newman, supra note 40, at 426 (stating after the Andersen case that "[c]orporate America could see both the resolve of the government to prosecute even the largest of corporations, as well as the consequences that could ensue from a company's refusal to settle"). 
written in 2005 by former SEC Commissioner and famed Stanford Law School professor Joseph Grundfest, who, in a claim rather ironically made just several years prior to the infamous bailout of American International Group, Inc., stated that "[i]f the government insists that A.I.G.'s chief executive be fired as part of the price of not indicting the firm, the chief executive is gone." 52

More recently, however, the DOJ has come under withering fire from the opposite flank, from critics who argue that DPAs are nothing more than ineffective sweetheart deals that do nothing to deter companies from breaking the law by allowing criminal companies to get off with a slap on the wrist. These critics typically argue that corporations should instead be subject to indictment and conviction in order to maintain a strong deterrent effect. $^{53}$ This perspective, one that tracks many of the populist feelings prevalent in the American consciousness today, is well-represented by the writings of Randall Eliason, a former fraud prosecutor from the U.S. Attorney's Office for the District of Columbia. As Mr. Eliason wrote of the increased use of DPAs:

With the threat of criminal liability effectively off the table, corporate executives may be more willing to skate aggressively close to the line - or to jump over it. If the prospect of real criminal sanctions against the company is removed, then engaging in criminal activity becomes just another dollars-andcents decision. The moral condemnation aspect of a criminal conviction is lost - and with it the unique deterrent value of criminal law. ${ }^{54}$

This brand of criticism recently reached a new height in the aftermath of the DOJ's December 2012 announcement that it had entered into a \$1.9 billion DPA with HSBC, the world's third-largest publicly held bank. HSBC stood accused of deliberately laundering billions of dollars in cash for violent international drug cartels such as the Mexican Sinaloa Cartel and the Colombian Norte del Valle Cartel, and of "violating U.S. sanctions for years by illegally conducting transactions on behalf of customers in Iran, Libya, Cuba, Sudan and Burma." ${ }^{55}$ Yet, despite these horrendous

52. Grundfest, supra note 40

53. Garrett, Globalized Corporate Prosecutions, supra note 11, at 1795.

54. Randall D. Eliason, We Need to Indict Them, Legal Times, Sept. 22, 2008; see also Sara Sun Beale, A Response to the Critics of Corporate Criminal Liability, 46 AM. CRIM. L. REV. 1481, 1482-86 (2009) (arguing that corporations, as large, powerful actors, are more than just legal fictions and should bear direct responsibility for their acts).

55. James O’Toole \& Charles Riley, HSBC Pays $\$ 1.9$ Billion to Settle U.S. Probe, CNNMoNEY (Dec. 11, 2012), http://money.cnn.com/2012/12/10/news/companies/hsbc- 
allegations, the DOJ was content with entering into a DPA with HSBC, with former Assistant Attorney General Breuer declaring that "HSBC is being held accountable for stunning failures of oversight." 56

The response was immediate and scathing. A New York Times editorial declared that it was "a dark day for the rule of law" and that "the government has bought into the notion that too big to fail is too big to jail." 57 Similarly, Professor William Black, a lead financial regulator during the Savings and Loan Crisis of the 1980s, noted that HSBC was "a recidivist of epic proportions" and blasted the DOJ and other regulators for "sham[ing] their institutions and professions, and betray[ing] their duty to the nation and citizenry." 58 Other commentators were more restrained yet still critical, noting that the DPA "raise[d] questions about whether such deals constitute real punishment for large corporations and serve to deter similar white-collar crime" and that the veracity of Breuer's claims that DPAs brought greater accountability for corporate wrongdoing was "far from clear." 59

And thus the controversy has raged. Yet, it has not been accompanied by any empirical attempt to determine whether the normal justifications given for using DPAs are legitimate. The primary reason given for the use of DPAs, of course, is the Andersen Effect. But no one has demonstrated that convictions actually cause a significant number of business failures among large corporations. ${ }^{60}$ In fact, some commentators have acknowledged in passing that most convictions do not drive corporations out of business. ${ }^{61}$ In other words, the national policy of preferring DPAs

money-laundering/.

56. Id.

57. Editorial, Too Big to Indict, N.Y. TIMES, Dec. 12, 2012, at A38.

58. William K. Black, Why Did Obama and Cameron Save a Criminal Enterprise Like HSBC?, HufFInGTON Post (Dec. 13, 2012), http://www.huffingtonpost.com/william-kblack/hsbc-settlement_b_2291859.html.

59. Alain Sherter, $\bar{H} S B C$ Bankers Dodge Personal Accountability, CBS MonEYwATCH (Dec. 12, 2012), http://www.cbsnews.com/8301-505123_162-57558734/hsbc-bankersdodge-personal-accountability/ (heavily citing an earlier version of this Article). Breuer announced his resignation a month later, in January 2013, shortly after appearing in the widely discussed Frontline documentary The Untouchables, in which he was critically questioned about his approach to prosecuting "Wall Street" fraud in the aftermath of the financial meltdown. Sarah Childress, Report: DOJ Criminal Chief Lanny Breuer Stepping Down, Frontline (Jan. 23, 2013), http://www.pbs.org/wgbh/pages/frontline/businesseconomy-financial-crisis/untouchables/report-doj-criminal-chief-lanny-breuer-steppingdown/.

60. See supra notes 13-14 and accompanying text.

61. See, e.g., Seigel, supra note 12, at 18 ("The collapse of [Andersen] as a result of being indicted was the exception, not the rule."); Ball \& Bolia, supra note 24, at 251 (acknowledging that "[n]o major corporation has been driven out of business by a 
over convictions is based on the fear of the Andersen Effect, but that fear is supported by nothing more than inconsistent anecdotal evidence. No one has ever checked to see if the Andersen Effect actually exists.

The second reason typically given for using DPAs is that DPAs can be used to make companies implement compliance programs, cooperate with individual prosecutions, and make other structural reforms. These benefits are normally not available when corporations are convicted at trial since they are not normal criminal penalties and typically may only be put in place by consent. However, part and parcel with this lack of empirical evidence for the Andersen Effect is the inconvenient fact that the oftenpresented dichotomy of "indictment vs. DPA" does not accurately reflect the nuanced landscape of the corporate prosecution battlefield. The DOJ is not dragging large corporations through epic, life-or-death trials; indictments are actually quite rare, and more than ninety percent of corporate convictions take place by plea agreement, just as they do in every other kind of federal criminal prosecution. ${ }^{62}$ In fiscal year 2010, for instance, 139 of the 145 organizations convicted in federal court were convicted by plea agreement. ${ }^{63}$

In effect, the literature has been looking in the wrong place. Indictments receive great attention, but only insofar as the demise of Arthur Andersen is recited so often as to become a catechism. DPAs have been extensively studied and debated in the literature. ${ }^{64}$ Yet, no one has checked to see whether corporations that are convicted actually suffer business failures, and, with the notable exception of Professor Garrett's important new work on the prosecution of foreign companies, ${ }^{65}$ no scholars have studied corporate guilty plea agreements to see whether they can be used to obtain the structural reform benefits of DPAs. ${ }^{66}$ This Article is meant to fill

government indictment since the Arthur Andersen case" (citing Joseph A. Grundfest, Over Before it Started, N.Y. TIMES, June 14, 2005, at A23)).

62. See Garrett, Globalized Corporate Prosecutions, supra note 11, at 1801, 1801 n.102 (stating this fact and noting that by Sentencing Commission statistics, only nine percent of convicted firms were convicted by trial verdict in the years 2000-2008).

63. U.S. Sentencing Commission, 2010 Sourcebook of Federal Sentencing STATISTICS tbl.53 (2010).

64. Compare Seigel, supra note 12, at 54 (arguing that prosecutors should be able to demand that corporations waive the attorney-client privilege as a condition of DPAs, but that additional protections should be added to protect individuals' right against selfincrimination), with Paulsen, supra note 40, at 1457-62 (criticizing the "Specter of Abuse" raised by the use of DPAs).

65. See generally Garrett, Globalized Corporate Prosecutions, supra note 11.

66. $C f$. id. at 1801 ("We know little about corporate convictions and guilty pleas generally.... [D]eferred and non-prosecution agreements have received scrutiny by Congress, the GAO, the DOJ, judges, the Bar, scholars, and corporations. Corporate 
both of these voids.

\section{METHODOLOGY}

\section{A. Dataset Construction}

To study the validity of the Andersen Effect and the structural benefits of corporate guilty pleas, it was necessary to obtain a comprehensive list of convicted companies. I began my research by creating a list of all publicly traded companies convicted of a federal criminal offense in the years 2001 to 2010. This was accomplished by utilizing the extensive, privately gathered collection of corporate plea agreements and docket sheets assembled and generously made publicly available by Professor Brandon Garrett of the University of Virginia School of Law. ${ }^{67}$ Although the U.S. Sentencing Commission reports that a total of 1,897 organizations were sentenced in the years 2001-2010, ${ }^{68}$ the Commission's statistics are incomplete, especially with regard to large corporations, and do not provide the kind of detailed data I needed in order to perform the study. ${ }^{69}$ At the time of the study, by contrast, Professor Garrett's database held the federal district court docket sheets for more than 1,700 federal criminal cases in which corporations were convicted, along with hundreds of plea agreements from those cases. ${ }^{70}$ Most importantly, the database was, and is, nearly comprehensive with respect to the cases involving large, publicly traded corporations convicted since $2000 .^{71}$

Starting with the 1,408 docket sheets provided by Professor Garrett's collection for the years 2001-2010 (representing more than seventy-four percent of the total organizational convictions for those years), ${ }^{72}$ I screened

convictions have not received such attention.”).

67. Garrett, Globalized Corporate Prosecutions, supra note 11, at 1807-08; Brandon L. Garrett \& Jon Ashley, Federal Organizational Plea Agreements, U. VA. ScH. OF LAW (last updated Oct. 10, 2011), http://lib.law.virginia.edu/Garrett/plea_agreements/home.php? $\mathrm{c}=3 \& \mathrm{~d}=0$.

68. This number may be arrived at by tabulating the annual statistics publicly released in the USSC's sourcebooks. Annual Reports \& Sourcebooks Archives, U.S. SENTENCING COMMISSION, http://www.ussc.gov/Data_and_Statistics/Archives.cfm (last visited Apr. 16, 2013).

69. Garrett, Globalized Corporate Prosecutions, supra note 11, at 1804-06.

70. By the time this Article was submitted for editing, the database had been expanded to include the docket sheets for more than 1,900 criminal cases. Garrett \& Ashley, supra note 67 .

71. Garrett, Globalized Corporate Prosecutions, supra note 11, at 1807-08.

72. See supra text accompanying note 63 . 
out all convictions of corporations that were not publicly traded when charged or convicted, defining a company as "publicly traded" if it had made a filing with the SEC and, at the time of charging or conviction, was traded on a major domestic or foreign stock exchange. Because my focus was on large companies, I excluded companies that were only listed on smaller exchanges like the NYSE MKT LLC (formerly called the American Stock Exchange, or AMEX) or traded on unlisted markets like the OTC Bulletin Board or Pink Sheets. The time of charging was defined as the moment that a criminal information or indictment was filed against the company in question, and the time of conviction as the moment a plea agreement was filed or a guilty verdict rendered. ${ }^{73}$

I performed the initial screening of SEC filings by conducting company name searches for each corporate defendant in the EDGAR database, the SEC's centralized tool for searching documents filed with the SEC. ${ }^{74}$ Because all public companies on major domestic exchanges and many companies on foreign exchanges have to make periodic SEC filings, the EDGAR searches allowed me to find every company-with the possible exception of some foreign companies that had never made any filings with the SEC - that had ever been listed on a major stock exchange, even if it later merged, changed its name, or went out of business. Of course, because many companies are required to make SEC filings even if they are not "public" as the term is colloquially used, the EDGAR searches were highly overinclusive and turned up a large number of false positives.

For quality control, after each EDGAR search, I conducted additional, secondary searches to determine whether the company in question was traded on a major domestic or foreign stock exchange at the time of its conviction. Generally, I performed secondary searches with tools like the Bloomberg BusinessWeek website ${ }^{75}$ and Google searches targeted for the appropriate time period. These secondary searches helped to exclude the large number of false positives that initially appeared to be publicly traded (such as private subsidiaries with names very similar to a publicly traded

73. Although I distinguished between the time of charging and the time of conviction, it should be noted that the distinction is irrelevant in the vast majority of cases. Generally, the government and the defendant arrange a plea agreement ahead of time and submit it shortly after the charging information is filed. Ultimately, the distinction between time of charging and time of conviction was not relevant to my study, as no company failed in the intervening period.

74. Company Search, U.S. SEC. \& ExCH. COMM'N, http://www.sec.gov/edgar/searched gar/companysearch.html (last visited Apr. 16, 2013).

75. Public Company Search, BloOMBerg Businessweek, http://investing.businesswe ek.com/research/common/symbollookup/symbollookup.asp?region=ALL\&letterIn=\&search Type $=$ coname $\& \mathrm{x}=0 \& \mathrm{y}=0 \&$ lookuptype $=$ public (last visited Apr. 16, 2013). 
parent company) and to catch the very small number of public companies, generally foreign ones that did not file Forms $10 \mathrm{~K}$ or $10 \mathrm{Q}$, that were overlooked in the initial EDGAR search. After I screened out all companies that did not meet my criteria, there remained a list of all publicly traded companies convicted during the ten-year period of 2001 to $2010 .^{76}$ These data are represented in Figure 1 below.

\section{B. Conviction Data and Fate After Conviction}

After obtaining a list of publicly traded companies convicted in the years 2001-2010, inclusive, I recorded their stock tickers and the exchanges they were listed on at the time of conviction. Each company was then coded by whether its primary listing was on a domestic or a foreign exchange, and also coded as one of the following eight market sectors: Energy, ${ }^{77}$ Manufacturing, ${ }^{78}$ Food ${ }^{79}$ Chemicals/Materials, ${ }^{80}$ Pharmaceuticals, ${ }^{81}$ Transportation, ${ }^{82}$ Defense, ${ }^{83}$ and Services. ${ }^{84}$ These

76. As discussed in the results, I obtained a lower final number of publicly traded corporations than did either the U.S. Sentencing Commission or Professor Garrett. The USSC reported sixty-three "openly traded" corporations for the years 2000-2009, nine more than my finding of fifty-four for the years 2001-2010. Garrett, Globalized Corporate Prosecutions, supra note 11, at 1807. I believe this discrepancy is because I excluded a number of small public companies traded on minor stock exchanges like the old AMEX, companies that likely would be included in the USSC's dataset. In contrast, Professor Garrett reported that 125 publicly traded corporations were convicted in the years 2000 2009. The disparity between Professor Garrett's findings and mine is due to our different definitions of what constitutes a publicly traded corporation. Professor Garrett coded as public all companies that made an SEC filing reported on the EDGAR database, while I only deemed companies to be public if they made an SEC filing and were listed on a major stock exchange at the time they were charged or convicted. Id. at 1807 n.129.

77. Companies in the Energy sector included utilities and all companies primarily involved in natural resources exploitation, predominantly the exploitation of oil and natural gas.

78. Companies in the Manufacturing sector included a variety of businesses primarily involved in making products other than specialized chemicals, pharmaceuticals, or national security products.

79. Companies in the Food sector included all those companies primarily involved in the production, distribution, or retail of foodstuffs.

80. Companies in the Chemicals/Materials sector included those involved in the refining of chemicals for purposes other than providing energy, as well as those companies that produced raw materials such as steel or aluminum.

81. Companies in the Pharmaceuticals sector included those involved in the production, marketing, and wholesale distribution of pharmaceutical drugs, medical devices, and other products used for medicinal purposes.

82. Companies in the Transportation sector included those involved in the trucking, 
results are presented in Figure 2. Next, the type of criminal charge the company pleaded to was coded as one of the following eight broad categories: Environmental/Food, ${ }^{85}$ Antitrust, False Statements/ Obstruction, ${ }^{86}$ Fraud, ${ }^{87}$ Pharma/Drug, FCPA, Export, and Terrorist Transactions. For companies that pleaded guilty to multiple violations from different categories, the violation was coded as the category that best reflected the conduct being charged; for example, for BAE Systems's plea to FCPA violations and to making false statements, the charges were coded as FCPA, which was the predominant offense with which the company was charged. ${ }^{88}$ These data are presented in Figure 3.

For each conviction, the following information was recorded: the total monetary penalty imposed (not counting special assessments), whether a corporate monitor or a compliance plan was put in place as part of the plea agreement, whether the corporation agreed to further cooperate with the government, and whether any other penalties, such as community service or a waiver of the attorney-client privilege, were imposed. Some of these data are presented in Figure 5, and the rest are presented in the Appendix.

Most importantly, for each conviction, I determined whether the corporate convict had suffered a business failure as a result of the conviction. First, I determined whether each convicted corporation was still listed under the same ticker on the same stock exchange that it had been listed on at the time of its conviction. If it was, it was counted as "Currently Active." For those corporations that were no longer listed, I determined what had happened to them and why. By using targeted Internet searches and by reviewing SEC filings when necessary, I searched for news and business articles that documented the time and nature of these companies' ultimate fates. For each company, I determined the class of event (e.g., a merger or bankruptcy) that had caused it to delist from its exchange. Next, I determined whether the event was a voluntary part of the

shipping, and air cargo industries.

83. Companies in the Defense sector included those primarily involved in manufacturing national-security related products or providing security and logistical services to the U.S. government overseas.

84. Companies in the Services sector included those primarily involved in providing professional or entertainment services.

85. This broad category included pollution violations of the Clean Air Act and Clean Water Act, violations of acts protecting certain plants and wildlife, violations of acts banning adulterated foods, and other, related violations.

86. This category included not only false statements and obstruction of justice, but also witness tampering and intimidation.

87. This category included all kinds of fraud, including securities fraud.

88. See infra app. A. 
corporation's business and viewed as a positive, or whether the corporation had been forced into the event by exigent circumstances. For those events that were positives for the company, such as a merger in which the acquirer bought out the old shares at a premium, the event was coded as a "Merger." For those where it appeared that the company's acts were involuntary (such as a hostile takeover), were voluntary but taken as a desperate move to save the company's business, or where the company simply went defunct, the event was coded as a "Business Failure." I then determined whether or not the conviction could reasonably be said to have been an important factor in the company's failure.

Finally, for each company not coded as "Currently Active," I determined the length of time that had passed between the conviction and the event that caused it to delist from its exchange, and noted all instances where a Merger or Business Failure occurred within three years of the conviction. These results, the heart of this Article, are presented in Figure 4.

\section{Rationales}

Performing an empirical study of corporate convictions is an undertaking fraught with practical obstacles. Given the lack of official tracking, there is no easily accessible, authoritative source of information on corporate prosecutions or convictions. Official sources provide limited data - the USSC's sourcebooks, for example, provide little more than the overall numbers of companies convicted each year. ${ }^{89}$ Privately collected databases, by contrast, may be more detailed but are unlikely to be comprehensive. Moreover, they are at the mercy of such uncontrollable factors as whether the prosecutor who drafted the plea agreement clearly outlined the plea's terms or whether the district court clerk correctly entered the corporate defendant's name on the docket sheet. Furthermore, the constantly shifting nature of the corporate entity is itself a barrier to study. The nearly infinite variations of ownership structure, webs of subsidiaries, waves of mergers, and nearly constant name changes that ripple through the corporate ecosystem-much of which can be surprisingly difficult to discern and decipher, even in the Internet era-all combine to make tracking corporations over time an exasperating

89. E.g., 2010 Sourcebook of Federal Sentencing Statistics, U.S. SENTENCING COMm'N, http://www.ussc.gov/Data_and_Statistics/Annual_Reports_and_Sourcebooks/2010/SBTOC 10.htm (last visited Apr. 16, 2013). 
endeavor, to say the least.

With these practical limitations in mind, I limited the scope of the study to a particular subset of companies: those that were (i) publicly traded and (ii) traded on a major stock exchange. I did this for several reasons. First, as a matter of practicality, it was essential to limit the study to companies about which a great deal of information is publicly available. This is the case with publicly traded corporations, which are widely followed in the popular press and are required to make numerous disclosures to investors. In contrast, the actions of private companies can be much more difficult to determine from publicly available information; determining whether a private company that went out of business in 2004 did so as a result of a conviction in 2002 could be a difficult, if not impossible, task.

Second, publicly traded companies disproportionately tend to be some of the largest and most important companies in existence. Determining the risk of putting them out of business is particularly important to making effective policy. ${ }^{90}$ Third, publicly traded companies can more easily be compared to one another, as they are similar in many respects. Public domestic corporations, of course, are overwhelmingly incorporated in the State of Delaware and are governed under Delaware corporate law. Most importantly, their ownership, though it can be diffuse or concentrated in a controlling shareholder that is its de facto owner, is not as variable as is the ownership of private corporations, which can have a variety of forms, from stand-alone companies owned by one or two individuals, to joint ventures between other companies, to wholly owned subsidiaries.

Fourth, publicly traded companies may very likely be more easily affected by a conviction than are private companies. Publicly traded corporations are players in the equity markets, and their stock price is extremely important to their health and survival. Their credit ratings and loan covenants are often tied to stock price; a conviction that causes investors to flee a publicly held corporation's stock could theoretically have devastating consequences to the corporation's ability to obtain credit and could indirectly cause a liquidity crisis. Private companies, by contrast, are not subject to this type of pressure and, in the case of wholly owned subsidiaries that can lean on their parent companies for funding, could theoretically be completely immune to such effects.

The study was limited to companies traded on a major stock exchange,

90. Cf. Garrett, Globalized Corporate Prosecutions, supra note 11, at 1805-06 (noting that convictions of "larger, public firms" with larger fines are "the more significant cases of the most interest to researchers"). 
excluding those traded on minor exchanges or on unlisted markets like the OTC Bulletin Board, for similar reasons. The requirement of being traded on a major exchange served as a rough proxy for company size and ensured that every corporation in the study was at least large enough to maintain a position on a major exchange. This avoided the potential sampling problem of making an apples-to-oranges comparison between industry giants and tiny companies with poorly regulated "over-the-counter" securities.

Moreover, though small companies comprise the vast bulk of convicted organizations, ${ }^{91}$ each individual small company has less of an impact on the economy and society than does each individual large company. Any business failure will have negative, often terrible effects on the owners and employees of that business, but the failure of a small company would not shake the entire nation as would the failure of, say, an

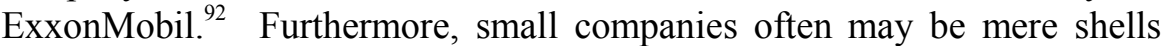
that use the corporate form to disguise a purely criminal enterprise. ${ }^{93}$ The failure of such a shell operation should be seen as a social benefit or, at the very least, it should not be seen as a negative. By contrast, the failure of a large company can have enormous effects, and those that are convicted, even those that have committed horrendous crimes, are almost always legitimate businesses. Limiting the scope to companies traded on major exchanges allowed this study to focus on the companies that proportionately have the most impact on society and thus are of the most interest to policymakers.

\section{RESULTS}

\section{A. Types of Companies and Charges}

Using the methodology described in the preceding Part, I obtained a list of fifty-four (54) separate federal convictions of publicly traded companies from the years 2001-2010..$^{4}$ All were convicted by guilty plea, and indictments were only filed in two cases. The majority of the

91. Id. at $1804-05$.

92. I use ExxonMobil Corp. as an example only because that company was indeed convicted in the year 2009. See infra app A.

93. Garrett, Globalized Corporate Prosecutions, supra note 11, at 1804-05.

94. Two companies, ICN Pharmaceuticals and Eli Lilly, were each convicted on two separate occasions. I count each instance separately to arrive at the total of fifty-four convictions. 
companies (34) were domestic, with a primary stock listing on either the NYSE or NASDAQ. The remaining twenty companies were primarily listed on major foreign stock exchanges, most of which were located in Asia or Western Europe. ${ }^{95}$ These data are presented in Figure 1 on the next page and in the Appendices. A wide variety of market sectors and industries were represented by the companies convicted. The most common sector was Manufacturing (13), followed by Food (8), Pharmaceuticals (7), Transportation (7), and Chemicals/Materials(7). Less common were the Energy (5), Defense (4), and Services (3) sectors. Conspicuously absent from the list were any banks or companies in the financial services sector. These data are represented in Figure 2, on the next page.

95. The total list of stock exchanges represented in this study were the NYSE, NASDAQ, Tokyo Stock Exchange, Frankfurt Stock Exchange, Euronext, London Stock Exchange, Korean Stock Exchange, Australian Stock Exchange, Toronto Stock Exchange, and Hong Kong Stock Exchange. See infra fig.1. 
Figure 1. Companies Listed by Stock Exchange $(n=$

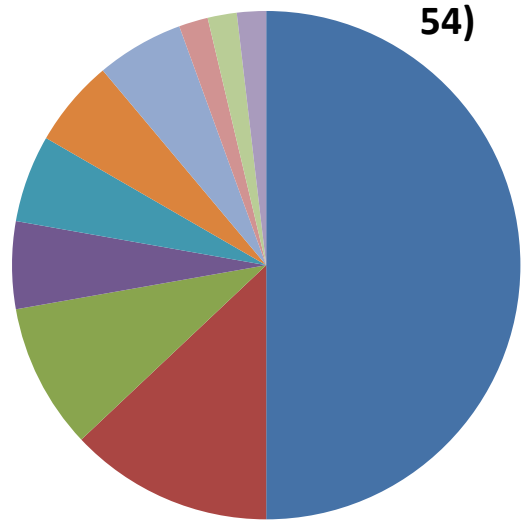

$$
\begin{aligned}
& \text { NYSE (27) } \\
& \text { NASDAQ (7) } \\
& \text { Tokyo SE (5) } \\
& \text { Frankfurt SE (3) } \\
& \text { Euronext (3) } \\
& \text { London SE (3) } \\
& \text { Korean SE (3) } \\
& \text { Hong Kong SE (1) } \\
& \text { Australian SE (1) } \\
& \text { Toronto SE (1) }
\end{aligned}
$$

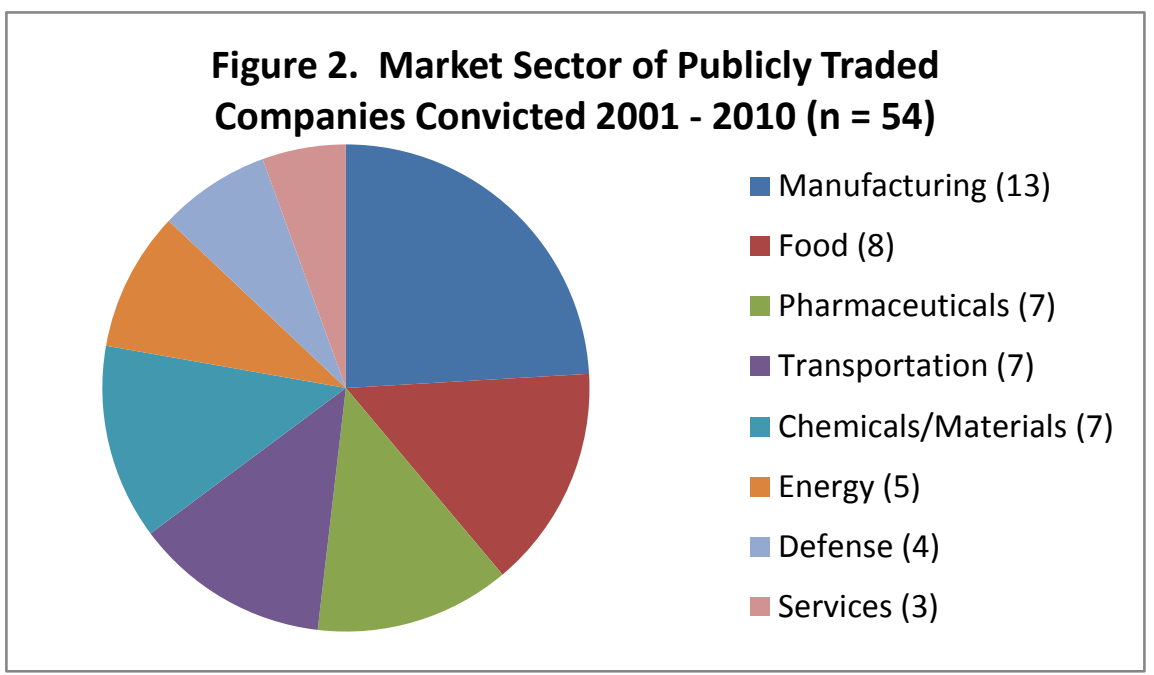

The predominant types of offenses were Environmental/Food Safety (19) and Antitrust (16). Other common offenses were False Statements/Obstruction (6), Pharma/Drug (4), and FCPA (4). Fraud (2), Export (2), and Terrorist Transactions (1) were also represented. The most notable absences from the list were those involving fraud and financial crimes, as only one instance of securities fraud was found. ${ }^{96}$ These data are represented in Figure 3.

96. See infra app. A. 


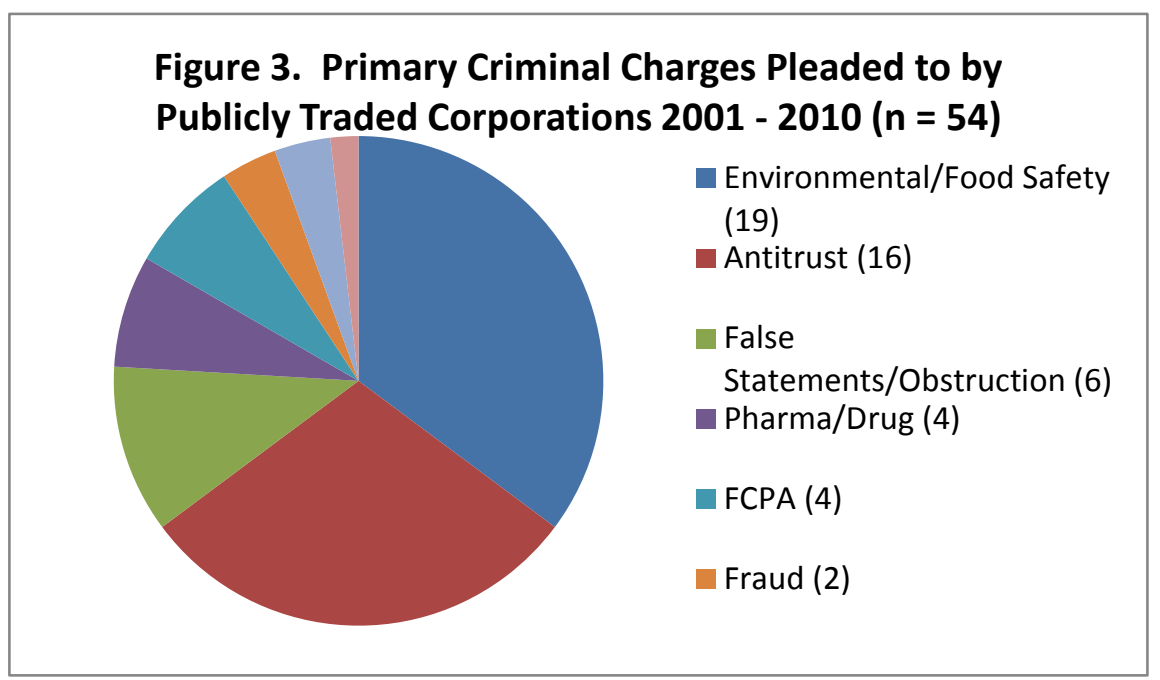

\section{B. Company Fates}

Of the fifty-four publicly traded companies convicted in the years 2001-2010, a large majority (37) are currently active, that is, they are listed on the same stock exchange that they were listed on at the time of their conviction, and they have not undergone a merger, acquisition, or name change. These data are shown in Figure 4. A smaller but still significant number (17) are no longer active on their original stock exchange under their original name, or are currently active under that name but only after suffering a business failure and reorganizing. Of those seventeen companies, twelve merged with or were acquired by another company under favorable circumstances that did not implicate a business failure. These were ICN Pharmaceuticals, ${ }^{97}$ MacDermid, ${ }^{98}$ OMI Corp.,${ }^{99}$ Crompton

97. As noted above, ICN was convicted twice, and for consistency is counted as two separate convictions. ICN changed its name in 2003 to Valeant Pharmaceuticals. See Ronald D. White, What's in a Name Change? A New Image, ICN Hopes, L.A. TIMES, Nov. 12,2003 , at B1 (discussing how ICN changed its name to Valeant Pharmaceuticals in order to escape a tarnished image). Valeant was acquired in 2010 in a transaction valued at $\$ 3.3$ billion. Pav Jordan \& Esha Dey, Drugmaker Biovail to Buy Valeant in $\$ 3.3$ Billion Deal, REUTERS (June 21, 2010, 5:03 PM), http://www.reuters.com/article/2010/06/21/us-biovailvaleant-idUSTRE65K1LA20100621.

98. MacDermid was acquired in 2006 in a transaction valued at $\$ 1.3$ billion, and shareholders received a premium on their shares. MacDermid Incorporated Announces Signing of Merger Agreement, Business WiRE News Release (Dec. 15, 2006), http://www. wnd.com/markets/news/read/797311/macdermid_incorporated_announces_signing_of_mer 


\section{Corp., ${ }^{100}$ Titan Corp., ${ }^{101}$ XTO Energy, ${ }^{102}$ Cephalon, ${ }^{103}$ Herley Industries, ${ }^{104}$ Rhodia,${ }^{105}$ Hynix Semiconductors, ${ }^{106}$ and British Airways. ${ }^{107}$}

ger_agreement.

99. OMI Corp. was acquired in 2007 in a transaction valued at $\$ 2.2$ billion. OMI Corp to Be Acquired by Teekay and TRMD for \$29.95 per Share, REUTERS (Apr. 17, 2007, 5:03 PM), http://www.reuters.com/article/2007/04/17/idUSIN20070417170349OMM20070417.

100. Crompton Corporation acquired and merged with Great Lake Chemical Corporation in 2005 (subsequently changing its name to Chemtura) in a deal that was apparently very favorable for investors. Crompton and Great Lakes Merge, ICIS.COM (Mar. 14, 2005, 12:01 AM), http://www.icis.com/Articles/2005/03/11/659739/crompton-andgreat-lakes-merge.html. The new company was led by Crompton's old board. Crompton Corporation and Great Lakes Chemical Corporation Announce Merger to Create Major New Specialty Chemicals Company, CHEMTURA (Mar. 9, 2005, 6:20 AM), $\mathrm{http}$ //investor.chemtura.com/press-release/great-lakes-historical/crompton-corporation-andgreat-lakes-chemical-corporation-annou.

101. Titan Corp. was acquired by L-3 Communications in June 2005, three months after being convicted of FCPA violations and paying a \$28.5 million fine. See infra app. B. News reports celebrated Titan's record revenues and stated that an earlier merger deal had fallen through because of the then-unresolved charges. L-3 Communications Acquires Titan, Defense Industry Daily (June 8, 2005, 8:21 AM), http://www.defenseindustrydai ly.com/13-communications-acquires-titan-0663/. The deal was valued at $\$ 2.65$ billion. $I d$.

102. XTO Energy was acquired by ExxonMobil Corp. in 2010 in a deal valued at $\$ 41$ billion. Michael J. de la Merced, Exxon Mobil to Buy XTO Energy for $\$ 31$ Billion, N.Y. Times DealBooK (Dec. 14, 2009, 8:24 AM), http://dealbook.nytimes.com/2009/12/14/ exxonmobil-to-buy-xto-energy-for-41-billion/.

103. Cephalon was acquired by Teva Pharmaceuticals in 2011 in a deal valued at $\$ 6.2$ billion. Naomi Kresge \& Robert Langreth, Teva Bets on Stem Cells, Cancer in \$6.2 Billion Bid for Cephalon, Bloomberg (May 2, 2011, 6:01 PM), http://www.bloomberg.com/n ews/2011-05-02/teva-to-acquire-cephalon-for-81-50-per-share-in-cash.html.

104. Herley Industries was acquired in 2011 by Kratos Defense and Security Solutions in a deal worth \$270 million. Kratos Acquiring Herley Industries, UNITED PRESS INT'L (Feb $8,2011, \quad 6: 30 \quad$ AM), http://www.upi.com/Business_News/Security-Industry/2011/ 02/08/Kratos-acquiring-Herley-Industries/UPI-45991297164637/.

105. Rhodia was acquired by the Solvay Group in 2011 in a deal valued at $€ 6.6$ billion. Will Beacham, Solvay Merger with Rhodia to Create Global Leader in Polymers and Consumer Products, ICIS: LoOK EAST FOR CHEMICALs (Apr. 4, 2011, 10:11 AM), http:// www.icis.com/blogs/east-european-chemicals/2011/04/solvay-merger-with-rhodia-tocreate-global-leader-in-polymers-and-consumer-products.html.

106. Hynix was partially bought out and merged with the South Korean conglomerate SK Telecom in 2011, in a deal valued at \$3.1 billion. Jun Yang \& Seonjin Cha, SK Telecom will Acquire 21\% Stake in Hynix Semiconductor for \$3.05 billion, BloOMBERG (Nov 14, 2011, 4:32 AM), http://www.bloomberg.com/news/2011-11-14/sk-telecom-will-acquire-21stake-in-hynix-semiconductor-for-3-05-billion.html.

107. British Airways merged with the Spanish airline Iberia in 2011. British Airways trades for Last Time Ahead of Iberia Merger, GuARDIAN (London) (Jan. 20, 2011, 3:26 PM), http://www.guardian.co.uk/business/2011/jan/20/british-airways-trades-last-timemerger. 


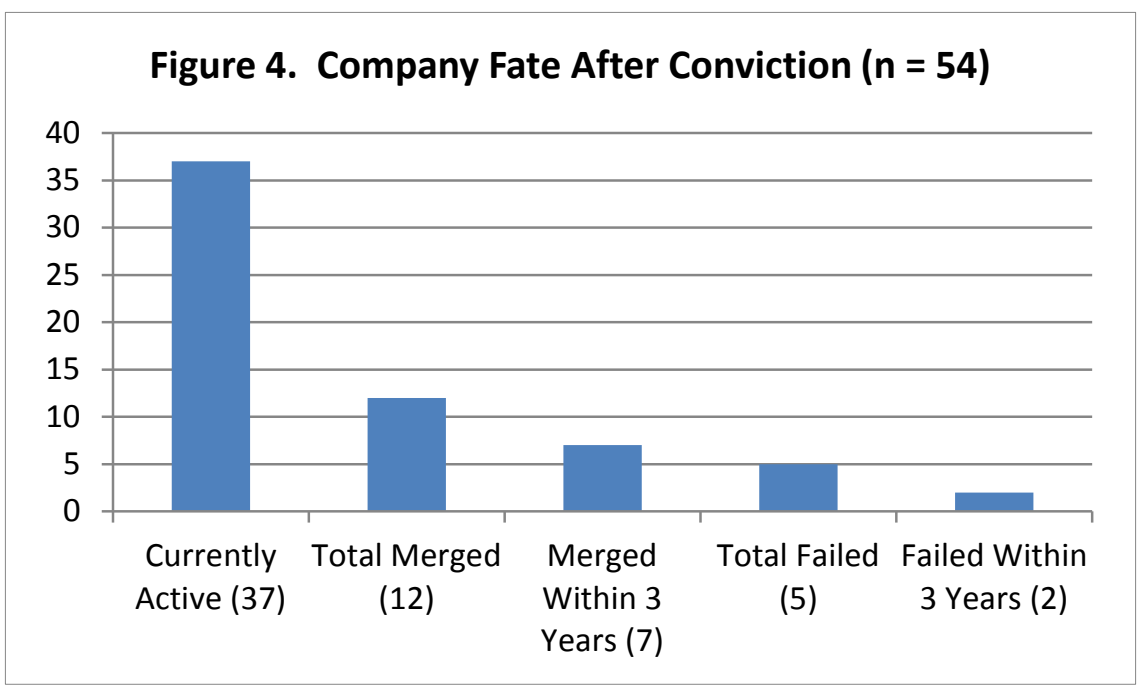

Thus, forty-nine of the fifty-four companies convicted in the years 2001-2010 are either currently active or are no longer active under their original name because of favorable mergers or acquisitions. But, in contrast to these ultimately successful companies, five companies suffered fates that could reasonably be described as business failures. These companies were Utilicorp United, Winn-Dixie Stores, Elpida Memory, Energy Partners, Ltd., and Japan Airlines International. ${ }^{108}$ Of these five companies, three filed for bankruptcy, while two were ultimately acquired by another company under conditions that could arguably be said to represent a business failure. However, none of the companies could reasonably be said to have suffered a business failure because of their convictions.

First off, three of the business failures - those of Utilicorp United, Winn-Dixie Stores, and Elpida Memory-occurred more than three years after the companies were convicted. ${ }^{109}$ This fact alone makes it extremely unlikely that the failures were caused by or related to the convictions. This conclusion is supported by contemporary accounts. Utilicorp, a formerly high-flying utility and energy trader that had copied many of Enron's shady methods, went into decline after the Enron scandal made its business highly suspect; its ultimate unfavorable acquisition in 2007 by another utility company had everything to do with the fact that investors thought the business shady, and nothing to do with the fact that it received a

108. See infra app. B.

109. See infra app. B. 
$\$ 1,000,000$ penalty for an environmental offense six years before. ${ }^{110}$ Likewise, Winn-Dixie was already in bankruptcy when it was convicted of an environmental offense, and it successfully reorganized several months afterwards; it was eventually bought out in 2011 after struggling to avoid a second bankruptcy. ${ }^{111}$ If the conviction were to have caused the failure, one would have expected the company to have never emerged from its first bankruptcy and to have gone straight into liquidation. Similarly, while Elpida Memory, a Japanese semiconductor manufacturer, received an $\$ 84$ million antitrust fine in March 2006, that conviction had little to do with its ultimate bankruptcy in February 2012, which occurred after a global downturn in the PC memory market made its core business and debt levels unsustainable. ${ }^{112}$

Contemporary accounts also show that the same is true for the two companies that went out of business within three years of being convicted. Japan Airlines International (JAL), the flag airline of Japan, filed for reorganization bankruptcy in January 2010, more than a year and a half after it pleaded guilty to an antitrust violation and paid a $\$ 110$ million fine. ${ }^{113}$ While this fine was indeed quite large, it pales in comparison to the

110. See infra apps. A, B. Utilicorp United changed its name to Aquila shortly after the Enron scandal. Utilicorp Changes Name to Aquila, Inc. Begins Trading Under Symbol ILA, GREAT Plains ENERGY (Mar. 18, 2002), http://phx.corporate-ir.net/phoenix.zhtml $? \mathrm{c}=96211 \& \mathrm{p}=$ irol-newsArticle $\& \mathrm{ID}=1201210 \&$ highlight $=$. It later was acquired by Great Plains Energy. Aquila Inc. Finally Sold After 5-Year Struggle, PIPELINE \& GAS J., Mar. 2007, at 2 ("The sale culminates Aquila's stunning downfall. Once ranked No. 33 on the Fortune 500 list of the nation's largest companies, Aquila was a victim of the energy trading debacle that occurred around the same [time] that Enron Corp. collapsed. Aquila lost billions of dollars in trading and in other unregulated businesses."); Lisa Lee, Great Plains Energy to buy Aquila for \$1.7 bln, REUTERS (Feb. 7, 2007, 1:58 PM), http://www.reuters.com/article/2007/02/07/businesspro-aquila-takeover-dc-

idUSN0737190420070207 (noting that investors were unhappy and opposed the merger because they were being bought out at a discount, an amount at less than what their shares were trading at on the open market).

111. Winn-Dixie entered bankruptcy in February 2005, was convicted in April 2006, and successfully reorganized in November 2006. John Dobosz, Winn-Dixie: The Beef People at a Bargain, Forbes: STOCK OF THE WeEK (Feb. 4, 2010, 1:50 PM), http://www.forbes.com/2010/02/04/winn-dixie-publix-personal-finance-investing-ideas-

supervalu-grocery.html; infra app. A. It was then bought out in late 2011 after continued brushes with going out of business. Winn Dixie Still Struggles, InVESTOPEDIA (Feb. 17, 2011), http://www.investopedia.com/stock-analysis/2011/Winn-Dixie-Still-StrugglesWINN-KR-SVU-WMT0217.aspx\#axzz1t05NwdC5; Mihir Dalal, Winn-Dixie to go private in $\$ 560 \mathrm{mln}$ Deal, ReuTERS (Dec. 19, 2011, 11:47 AM), http://www.reuters.com/article/2 011/12/19/winndixiestores-biloidUSL3E7NJ4BA20111219.

112. Hiroko Tabuchi, Japanese Computer Chip Maker Files for Bankruptcy, N.Y. Times, Feb. 27, 2012, at B4.

113. Japan Airlines Files for Bankruptcy Protection, BBC NEws (Jan. 19, 2010, 11:57 
\$25 billion of debt it owned at the time it filed for bankruptcy. ${ }^{114}$ Moreover, news articles at the time blamed JAL's failure on market conditions such as rising fuel prices, declining passenger volume, and increased competition from rival airlines, but did not mention the conviction. ${ }^{115}$ JAL was the victim of the global economy and its own financial problems. It was not driven out of business by its conviction.

The only domestic company to suffer a business failure within three years of conviction was Energy Partners, Ltd. (EPL), a New Orleans-based energy company traded on the NYSE. EPL was convicted of a minor environmental offense in February 2008 and sentenced to pay a $\$ 75,000$ fine along with an additional $\$ 25,000$ community service penalty. ${ }^{116} \mathrm{~A}$ year later, after suffering financial troubles, it was delisted from the NYSE, and in May 2009, with its business "struggl[ing] with deteriorating commodity prices and lengthy hurricane shutdowns," it filed for chapter 11 reorganization bankruptcy. ${ }^{117}$ The company, which suffered losses of between $\$ 40$ and $\$ 50$ million in 2008, blamed its financial troubles on "a combination of lower oil and natural gas prices and anticipated reduced capital spending based on the lower commodity price environment." "118 As reported at the time, the President of the Louisiana Oil and Gas Association supported this assessment by stating that EPL's "predicament is an extreme version of a situation many energy companies are facing in Louisiana and across the nation." 119 Like Elpida and JAL, EPL was driven to failure by its own debt load and the global economic collapse. There is no plausible reason to suspect that a minor environmental conviction was the straw that broke the company's back.

AM), http://news.bbc.co.uk/2/hi/8466997.stm; infra app. B.

114. Mayumi Negishi \& Mariko Katsumura, Japan Airlines Files for $\$ 25$ Billion Bankruptcy, REUTERS (Jan. 19, 2010, 12:40 PM), http://www.reuters.com/article/2010/01/19 /us-jal-idUSTRE60H4NA20100119.

115. Id.; Japan Airlines Files for Bankruptcy Protection, supra note 113.

116. See infra app. B (showing a total of $\$ 100,000$ in penalties for EPL).

117. Kimberly Quillen, Energy Partners Files Chapter 11 Bankruptcy, TIMES-PICAYUNE (New Orleans) (May 1, 2009, 10:56 AM), http://www.nola.com/business/index.ssf/200 9/05/energy_partners_files_chapter.html; Jen DeGregorio, Energy Partners to Be Delisted from New York Stock Exchange, Times-PicAYUnE (New Orleans) (Mar. 25, 2009, 5:23 PM), http://blog.nola.com/tpmoney/2009/03/energy_partners_to_be_delisted.html.

118. DeGregorio, supra note 117.

119. Id. 


\section{Plea Characteristics}

The fifty-four convictions in this sample reveal a wealth of data on corporation plea agreements, the most important of which are presented in Figure 5. The total monetary penalties attached to a conviction ranged from a diminutive $\$ 20,000$ environmental fine on XTO Energy to an enormous $\$ 1.615$ billion total penalty on Eli Lilly for distributing and advertising misbranded pharmaceuticals. ${ }^{120}$ Of the fifty-four convictions in this study, forty-three involved a monetary penalty greater than $\$ 1$ million, twenty-eight involved a penalty greater than $\$ 10$ million, and thirteen involved a penalty greater than $\$ 100$ million.

More importantly, many of the convictions in this study contained agreements to implement the kinds of structural reforms that are usually thought of as only being obtainable through the use of DPAs. While plea agreements were only available for thirty-four of the fifty-four convictions, the agreements that were available, when combined with the courts' docket sheets, allow for a partial picture of what may be achieved with plea agreements.

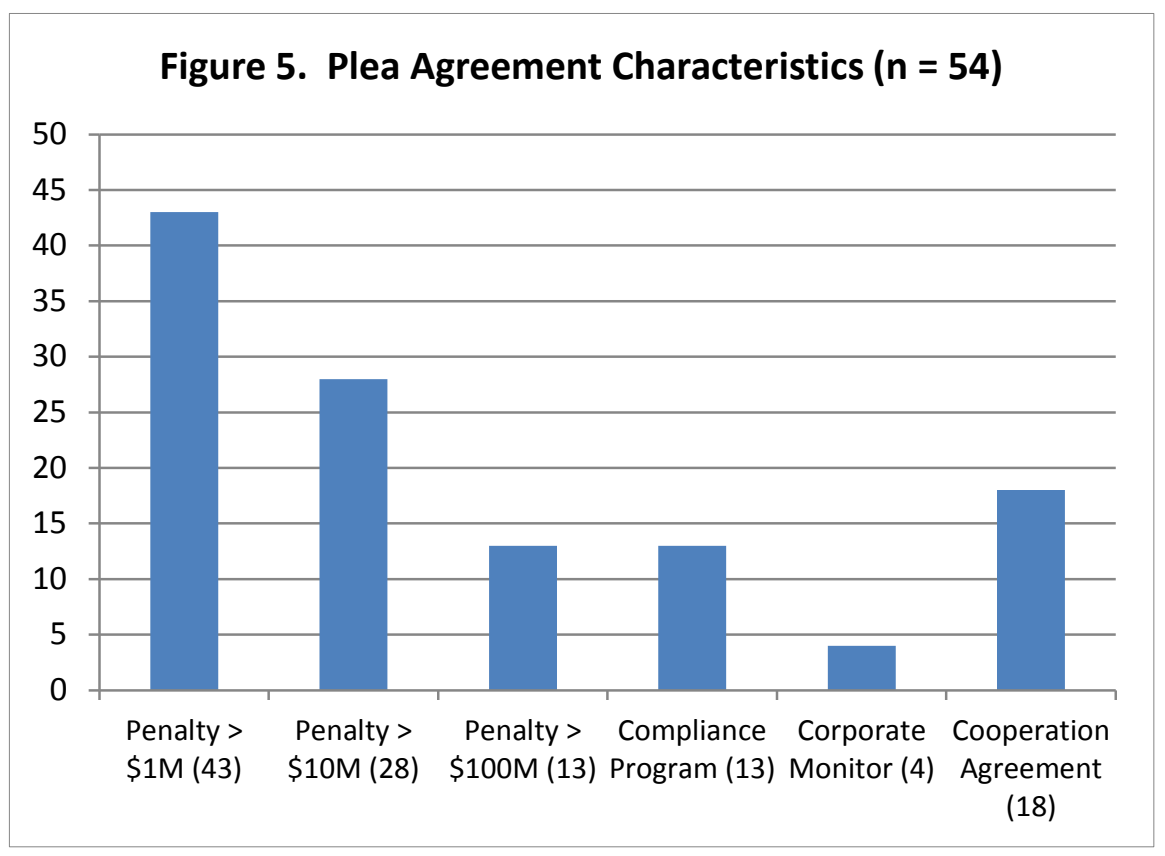

120. See infra app. B (detailing the range of plea penalties for public companies convicted in the years 2001-2010). 
One-third (18) of the guilty pleas contained agreements that the defendant corporation would fully and completely cooperate with the government's investigation into other aspects of the defendant's business, with parallel civil litigation, or in prosecutions of individual corporate officers. Nearly one-quarter (13) also contained compliance programs, most of which were extremely detailed in the same fashion as are compliance plans put in place through DPAs. Additionally, several (4) guilty pleas required the defendant corporations to hire corporate monitors to conduct independent oversight of their businesses. Finally, one plea agreement required a defendant to make a partial waiver of its attorneyclient privilege ${ }^{121}$ and one plea agreement required the defendant to perform community service.

\section{Implications: No Evidence of an Andersen Effect}

No public company convicted in the years 2001-2010 went out of business because of a federal criminal conviction. This result calls the conventional wisdom about the Andersen Effect into serious doubt. If it were true that "prosecution alone [can] destroy even the most established of companies," then at least some of the public companies convicted in the years 2001-2010 should have gone out of business following their convictions. ${ }^{122}$ Yet none of them did.

What explains this result? Several possible explanations come to mind. First and most obviously, the destruction of a company by a conviction could be the exception rather than the rule. Second, it could be possible that it is the uncertainty of indictment and possible conviction at trial, rather than the mere fact of a conviction negotiated by plea agreement, that destroys companies. It is logical to assume that, because cooperation can allow defendants to negotiate for lower penalties, companies convicted by plea agreement would have a better chance of survival than companies convicted at trial. Third, it could simply be that the DOJ is only prosecuting companies that are "healthy" enough to survive a conviction. All of these explanations are at least plausible, though none are completely satisfactory.

The first explanation, which I believe is the most likely to be true, is that the Andersen Effect, that is, the possibility of driving a company out of

121. The privilege waiver was required in the case of Chiquita Brands International, which, in March 2007, was convicted of transacting with terrorist groups. Infra apps. A, B.

122. Paulsen, supra note 40, at 1436. 
business through the collateral consequences of prosecution, is generally not a threat to most large public companies. Only five of the companies in this study went out of business, and none of them did so under circumstances that could plausibly be connected to their convictions. ${ }^{123}$ This is not to say, of course, that convictions can never cause established companies to fail. Arthur Andersen itself would appear to be proof of that possibility, though it should be remembered that Andersen was a professional services partnership and thus subject to different stresses than are most public companies. And it is certainly possible - or even certainthat there are many small, private companies that suffered business failures but fell outside this study's criteria. Even if most companies would not be threatened by most convictions, the mere fact that the companies in this study survived does not foreclose the possibility that some companies could be placed at risk of going out of business because of a conviction. Those caveats aside, the fact remains that the complete absence of conviction-related failures strongly supports the conclusion that the Andersen Effect does not exist.

The second possible explanation is that it is indictment and conviction by jury verdict that is deadly to the corporate defendant, rather than mere conviction by guilty plea. As noted, more than ninety percent of convictions of organizations in the federal system happen through guilty plea, ${ }^{124}$ but Andersen was convicted at trial. It is not implausible that the Andersen Effect might be limited to convictions obtained by indictment and guilty verdict. My data are inconclusive on this point. As discussed, all fifty-four convictions in this study occurred by plea agreement, while only two of the companies were initially charged by indictment. Interestingly, neither of those two companies (Overseas Shipholding Group and Herley Industries) was among the five companies that suffered business failures. ${ }^{125}$ But even if it is the rare indictment and conviction by guilty verdict that is the true corporation-killer, the sheer rarity of indictment and trial still leaves the Andersen Effect as the exception and not the rule. Most convictions will still occur by plea agreement and will not give prosecutors or policymakers cause for concern.

The third possible explanation could be that prosecutions are occurring selectively for fear of the Andersen Effect or for some other reason. As already noted, the original Holder Memo stated that prosecutors

123. See supra section III.B.

124. Supra note 57 and accompanying text.

125. See infra app. B (reporting that Overseas Shipholding Group is still active and Herley Industries has merged with another corporation). 
should consider potential collateral consequences in making charging decisions. ${ }^{126}$ Moreover, in his recent remarks, former Assistant Attorney General Breuer went to great lengths to explain how the DOJ takes potential collateral consequences into account when it makes charging decisions. ${ }^{127}$ Furthermore, the current literature suggests that prosecutors target certain market sectors for prosecution and others for DPAs, and my data add some additional support to that conclusion. ${ }^{128}$ Of the companies in my dataset, nearly all were firms like chemical companies, manufacturing companies, and shipping companies-all companies that make or utilize tangible products and materials. By contrast, firms that provided intangible services such as investment banking were entirely absent from the list of convicted companies. ${ }^{129}$ In fact, no public companies involved in the financial sector were convicted in the years 2001-2010, a result that is particularly provocative in light of the current controversy over the government's failure to aggressively prosecute firms and individuals involved in the recent financial crisis. ${ }^{130}$ Likewise, thirty-five of the fiftyfour convictions in my dataset were for environmental and antitrust offenses, respectively, but only two convictions were for offenses involving fraud.

126. Holder Memo, supra note 25.

127. See Breuer, supra note 46 (explaining how the DOJ considers the effects of a charge on innocent employees, shareholders, the health of a particular industry, and the market as a whole).

128. Notably, Professor Garrett found that foreign companies, which were mainly large firms, were primarily being convicted of antitrust and environmental violations, while firms being targeted for fraud violations received a disproportionate number of DPAs. Garrett, Globalized Corporate Prosecutions, supra note 11, at 1874-76 figs.4-6.

129. See infra app. A (showing that the list of convicted companies does not include any that provide such services).

130. See infra apps. A, B (reporting that companies in the financial sector are not on the list of convicted companies). Many commentators, particularly those in the popular press, have castigated the government's failure to prosecute "Wall Street." See, e.g., William Greider, How Wall Street Crooks Get out of Jail Free, The NATION, Apr. 11, 2011, at 11-14 (describing the government's unwillingness to prosecute Wall Street following the financial crisis as a conflict of values where corporate capitalism has defeated society's sense of right and wrong); Morgenson \& Story, supra note 45 (noting that prosecutors have largely ceased prosecuting financial firms in favor of using DPAs); Alex Pareene, No One Went to Jail, so Why is Wall Street So Mad?, SALON (May 7, 2012, 3:23 PM), http://www.salon.com/2012/ 05/07/no_one went to jail_so_why is_wall_street_so mad/ (arguing that President Obama's inaction has only emboldened those individuals involved in the financial crisis because they have faced no legal repercussions); Matt Taibbi, Why Isn't Wall Street in Jail?, ROLLING STONE (Feb. 16, 2011, 9:00 AM), http://www.rollingstone.com/politics/news/whyisnt-wall-street-in-jail-20110216 (providing details about a variety of cases against Wall Street firms that did not result in any convictions and characterizing the SEC as ineffective and corrupt). 
Thus, it is possible that prosecutors may be selectively prosecuting companies that they believe can stand the shock of conviction while they are entering into DPAs with companies that they fear would fail if convicted. Unfortunately, the evidence neither supports nor casts doubt on this explanation. While the data show that prosecutors disproportionately pursue convictions for some offenses while they instead pursue DPAs for others, the data alone cannot tell us why prosecutors are taking these actions. And even if the DOJ is declining to prosecute companies for fear of the Andersen Effect, there is no evidence that its fear is justified or that the companies ultimately convicted are any healthier than those that receive DPAs. While a future article could further explore this possibility, perhaps by comparing the market fundamentals of convicted companies to the fundamentals of companies that receive DPAs, the current evidence is inconclusive on this point.

Though the possibility that the DOJ is preempting the Andersen Effect by pursuing DPAs when companies are at risk cannot be entirely discounted, there is no data to support it either. One clear result remains: No company publicly traded on a major stock exchange failed because of a conviction that occurred in the years 2001-2010. There is no empirical evidence to support the existence of the Andersen Effect.

\section{E. Implications: Structural Reforms May Be Obtained Through Convictions}

Additionally, as part of their plea bargains, many convicted companies in this study agreed to the exact types of detailed compliance programs and structural reforms that DPAs often implement. Of the fifty-four convictions, thirteen involved the implementation of a compliance program while four involved the implementation of a corporate monitor. ${ }^{131}$ Of these, all of the convictions that implemented corporate monitors and ten of the thirteen convictions implementing compliance programs came after the year 2006, likely indicating that the DOJ only recently began to regularly use plea agreements to obtain such reforms. ${ }^{132}$

These results call into question the necessity of using DPAs as a means to impose compliance programs and corporate monitors on lawbreaking companies. Guilty pleas can and increasingly are being used to obtain the implementation of the types of structural reforms often thought

131. See infra app. B.

132. See infra apps. A, B. 
of as being exclusive to DPAs.

\section{OUtLINING A “CORE BuSINESS MODEL” OF CORPORATE CRIMINAL PROSECUTIONS}

The data presented above do not prove that companies never go out of business because of convictions, but they indisputably show that the conventional wisdom is more than misguided: It is simply wrong. Prosecution may drive large companies out of business in some rare situations, but it is not the "corporate death penalty" that ideological hyperbole has made it out to be. In fact, in the absence of evidence to the contrary, prosecutors, defense counsel, and policymakers should assume that convictions will only cause large companies to suffer business failures in extraordinary situations.

Of course, even though it is the rare situation where a prosecution dooms a company, the consequences of such a failure, if it occurs, may very well be disastrous. Like the doctor who needs to know when a particular patient is predisposed towards heart disease, prosecutors and policymakers need to know when a particular corporation is at risk of failing if prosecuted. The remainder of this Article briefly describes a new model for predicting when convictions are likely to destroy corporations, and it explains what new steps should be taken in light of this model.

I hypothesize that, in the overwhelming majority of situations, a conviction will only cause a corporation to go out of business when it threatens the corporation's ability to conduct its core business. As a starting point for this model, I draw on one of the tenets of rational choice theory. Namely, I assume that the markets and most of the major players in those markets are, on the whole, economically rational actors that act in their own financial self-interest. This assumption is critical because it provides a basis for determining, in any given situation, how and why a company might go out of business. While many commentators point towards reputational damage, disbarment, and other collateral consequences of conviction, there is little broader effort to understand the causal chain of events that leads from conviction to business failure.

With that assumption in mind, I next divide the possible consequences of conviction into two broad categories: acute harms and structural harms. Acute harms are those that will have short-term consequences but are oneoff events that, if survived, do not implicate the corporation's long-term chance of survival. Typical examples of such harms would be most monetary penalties, damaged credit ratings, and general reputational 
damage. These harms can be very damaging, for sure, and can cause decreased revenues or conceivably even trigger liquidity crises in certain circumstances. Yet, in most situations, they do not cast doubt upon a large corporation's chance of survival. Structural harms, by contrast, are those which are both long-lasting and which make the corporation unable or less able to produce or market its core products and services. These harms could appear in a variety of forms, but all follow a pattern: Where the conviction would eliminate the demand for the corporation's products or services in a marketplace of economically rational actors or eliminate the corporation's ability to provide those products or services, a structural harm will occur and the corporation's viability will be threatened.

Consider two hypothetical examples: Greedy Corporation and Evil Corporation. ${ }^{133}$ Greedy Corporation, a large manufacturer of components used in widget production, pleads guilty to antitrust violations for fixing the prices of its widget components, is fined $\$ 1$ billion, and is forced to appoint a corporate monitor and begin an expensive, intrusive compliance program. Greedy has to revise its future earnings expectations downwards, and its credit rating is cut to near-junk status. Greedy has suffered only acute harms; while its profitability and ability to obtain credit has decreased, its core business has not been impacted. Greedy can still make its widget components, and the widget-makers will still buy them in order to build their widgets. Any reputational harm to Greedy will be largely irrelevant; the companies that purchase its products may be displeased upon learning that they had been swindled in the past, but they still need to make widgets, and Greedy's crime does not call into question its ability to make desirable widget components. In the absence of some other problem, Greedy will survive.

Evil Corporation, by contrast, is a large defense contractor that is convicted of committing arms export violations. While it is a multibilliondollar business, nearly half of its revenue comes from its main customer, the federal government. Upon its conviction, the government excludes Evil from all government contracts for the indefinite future. The conviction has thus caused a lasting decrease in the demand for Evil's products in the marketplace, and Evil has thus suffered a severe structural harm. Investors will likely desert it, and its business may be likely to fail.

The existing evidence supports the Core Business Model that I propose. Most of the companies in the dataset suffered severe acute harms as a result of their convictions, but did not suffer structural harms. Eli Lilly, the pharmaceuticals giant, pleaded guilty in 2009 to selling

133. With apologies to Professor Jens Dammann. 
misbranded drugs, agreed to pay $\$ 1.65$ billion in criminal fines and civil settlements, and agreed to a compliance plan. ${ }^{134}$ These harms were all acute harms, however, and because Eli Lilly was not excluded from participation in government health programs, it continued to produce and sell pharmaceutical products. Eli Lilly is still in business today. This makes perfect sense. Few economically rational actors would stop prescribing or purchasing drugs for legitimate, necessary uses simply because the drugs had previously been misbranded. Doctors and customers might trust Eli Lilly less or potentially treat the company with moral opprobrium, but that would not stop more than an insignificant number of them from prescribing and consuming its drugs.

Likewise, Chiquita Brands International, the large produce company, pleaded guilty in 2007 to transacting with designated Colombian terrorist groups. ${ }^{135}$ One might assume that "palling around with terrorists" in such a manner would be an unforgiveable sin these days, but that assumption would be mistaken. Chiquita's conviction caused it no structural harms, as it did not affect Chiquita's ability to make and deliver produce to its customers, and any reputational damage it may have suffered did not cause it structural harm. In the absence of a widespread boycott based on moral outrage, no economically rational retailer would stop buying Chiquita's bananas regardless of what atrocities the corporation contributed to in South America.

An even more potent example of this principle can be found in the recent conviction of the multinational energy giant, BP. In November 2012, BP pleaded guilty for its conduct in the Deepwater Horizon oil spill to eleven counts of felony manslaughter, one count of felony obstruction of Congress, and violations of the Clean Water Act and Migratory Bird Treaty Act. ${ }^{136}$ As part of its plea, BP - a company that had previously been convicted several times, including for an explosion at its Texas City refinery in 2005 that killed fifteen workers - was sentenced to pay a record $\$ 4$ billion in criminal penalties. ${ }^{137}$ Yet, BP was not banned from drilling on public lands and only received a temporary suspension from receiving

134. See infra apps. A, B.

135. See infra apps. A, B.

136. Press Release, BP Exploration and Production Inc. Agrees to Plead Guilty to Felony Manslaughter, Environmental Crimes and Obstruction of Congress Surrounding Deepwater Horizon Incident, U.S. DEP'T OF Justice (Nov. 15, 2012), http://www.justice.gov/opa/pr/2012/November/12-ag-1369.html.

137. Abrahm Lustgarten, A Stain That Won't Wash Away, N.Y. Times, Apr. 20, 2012, at A23. 
government contracts, and thus it suffered no structural harms. ${ }^{138}$ As the Core Business Model would predict, its stock price barely moved, and the company remains hugely profitable, much to the distress of the many who advocated that the company receive a far more severe sanction for the criminal negligence that caused the largest environmental catastrophe in U.S. history. ${ }^{139}$

By contrast, Utilicorp United was forced into an unfavorable merger because of weakness in its core energy trading business, a weakness that arose from its investors' fundamental distrust of the energy trading model that Utilicorp used. ${ }^{140}$ This weakness (though unrelated to its conviction) caused Utilicorp structural harm by preventing it from being able to successfully monetize that sector of its business, and it ultimately drove the company to seek an unfavorable merger.

The fate of Arthur Andersen itself fits well in the Core Business Model. The fall of Enron and Andersen's subsequent indictment and conviction caused an enormous structural harm to Andersen by destroying the value of its product. Andersen, one of the "big five" accounting firms, was a hugely prestigious organization. Its core product was not simply accounting services; rather, it was the trustworthiness of its name. Andersen's clients utilized its services as a way to tell the government and their own creditors and investors that their books were overseen by a trustworthy, highly reputable accountant. That trustworthiness was exactly what was destroyed by the Enron scandal and Andersen's conviction. With its reputation shattered, Andersen had no product to offer.

\section{CONCLUSION}

Using the Core Business Model as a starting point, both the DOJ and corporate defense counsel should change their respective strategies. The DOJ in particular should radically revamp its much criticized program of using DPAs by increasing its willingness to demand guilty pleas of corporate defendants, and, if necessary, issuing indictments and taking

138. Roberta Rampton \& Timothy Gardner, U.S. Bans BP From New Government Contracts After Oil Spill Deal, REUTERS (Nov. 28, 2012), http://www.reuters.com/article/ 2012/11/28/us-bp-contracts-idUSBRE8AR0M120121128.

139. See, e.g., Tyson Slocum, Public Citizen's Take on BP Settlement, CitizenVox (Nov. 15, 2012), http://www.citizenvox.org/2012/11/15/public-citizen-bp-settlement/ (attacking the criminal plea as "pathetic" and "inadequate to address BP's repeated criminal conduct").

140. See supra notes $104-05$ and accompanying text. 
defendants to trial. By basing its actions on the knowledge that most corporations will not go out of business if convicted and by using the core business model to predict which corporations might be at risk, the DOJ can confidently prosecute more companies without fear of creating another Andersen-style collapse. The DOJ should continue to use DPAs only in those instances where the Core Business Model predicts that a prosecution might actually threaten a company's survival.

Such a shift towards increased prosecutions and away from DPAs would both increase deterrence of corporate wrongdoing and further the interests of justice. The data show that the two main reasons for using DPAs - the Andersen Effect and the supposed inability to gain compliance programs and structural reforms through guilty pleas - are largely invalid. The Core Business Model can be used to help predict those rare situations where business failures may occur, and the data show that plea agreements can be used to obtain structural reforms just as successfully as DPAs can. With this new information, there is little justification for using DPAs in most cases. Prosecutors should seek convictions when they can, use DPAs only when they absolutely must, and decline to prosecute when they have a weak case that can only be successfully prosecuted by improperly pressuring a defendant. By adopting these methods, the DOJ can both increase deterrence of corporate crime and operate in a manner that is more transparent and more respectful of defendants' rights. ${ }^{141}$

Likewise, defense counsel should recognize that the effects of corporate convictions are widely overstated-particularly given the government's apparent reluctance to bar convicted companies from government contracts - and that the Core Business Model can be used to help predict which offenses a defendant can safely plead to. Though a

141. In the time since this Article was submitted for editing, there has been some indication that a shift in the direction I recommend may, in fact, be beginning. In the weeks after the DOJ announced the now-infamous HSBC DPA, it finalized guilty plea agreements with the Japanese subsidiaries of two banks, UBS and the Royal Bank of Scotland, as part of larger settlements (complete with DPAs for the parent companies) of those companies' involvement in the LIBOR interest-rate rigging scandal. Ben Protess, Prosecutors, Shifting Strategy, Build New Wall Street Cases, N.Y. Times Dealbook (Feb. 18, 2013, 10:00 PM) [hereinafter Prostess, New Wall Street Cases], http://dealbook.nytimes.com/2013/02/18/prosecutors-build-a-better-strategy-to-go-afterwall-street/?hp. These prosecutions were the first to target global banking companies in two decades. Ben Protess, Leniency Denied, UBS Unit Admits Guilt in Rate Case, N.Y. TIMES DEALBOOK (Dec. 19, 2012, 9:46 PM), http://dealbook.nytimes.com/2012/12/19/leniencydenied-ubs-unit-admits-guilt-in-rate-case/?hp. Though these cases only involved foreign subsidiaries, there is some speculation that the DOJ is laying the groundwork for prosecutions of parent financial companies. Protess, New Wall Street Cases, supra. Only time will tell. 
guilty plea will necessarily involve admitting to a crime and accepting the resulting stigma, pleading guilty may be the preferable option in some cases, particularly if doing so would allow the defendant to avoid agreeing to certain onerous structural reforms that might be attached to a DPA. And in some extreme cases, if the prosecution has a particularly weak case but still demands a harsh DPA, it may even be preferable to roll the dice and go to trial.

Corporate prosecutions are a necessary part of the modern American legal system. This Article has attempted to answer one of the most pressing issues in this area of the law: whether and when corporations may be prosecuted without driving them out of business and causing terrible consequences to society and the economy. The important, often emotional, and highly political topic of corporate criminal prosecutions has escaped empirical scrutiny for too long. It is time to cast aside the gut feelings and ideological truisms that have thus far dominated the debate and begin basing our policies on cold data. By showing that there is no evidence that the "Andersen Effect" exists and thus that the "corporate death penalty" is no more than a bogeyman, by showing that plea agreements can be used to obtain structural reforms, and by formulating the basis for a new Core Business Model of corporate prosecutions, this Article provides a starting point for an informed, data-driven debate on when and how corporate criminal prosecutions should occur. 
Appendix A. Companies Convicted 2001 - 2010, With Market Sector and Offense

\begin{tabular}{|c|c|c|c|c|}
\hline Company & $\begin{array}{c}\text { Conviction } \\
\text { Date }\end{array}$ & $\begin{array}{c}\text { Exchange - } \\
\text { Ticker }\end{array}$ & Sector & Offense \\
\hline Utilicorp United & Mar. 2001 & NYSE - UCU & Energy & $\begin{array}{l}\text { Environmental/Food } \\
\text { Safety }\end{array}$ \\
\hline Kaydon Corp. & Apr. 2001 & NYSE - KDN & Manufacturing & $\begin{array}{l}\text { False Statements/ } \\
\text { Obstruction }\end{array}$ \\
\hline Sara Lee Corp. & June 2001 & NYSE - SLE & Food & $\begin{array}{l}\text { Environmental/Food } \\
\text { Safety }\end{array}$ \\
\hline MacDermid, Inc. & Nov. 2001 & NYSE - MRD & $\begin{array}{l}\text { Chemicals/ } \\
\text { Materials }\end{array}$ & $\begin{array}{l}\text { Environmental/Food } \\
\text { Safety }\end{array}$ \\
\hline $\begin{array}{c}\text { ICN } \\
\text { Pharmaceuticals }\end{array}$ & Dec. 2001 & NYSE - ICN & Pharmaceuticals & Fraud \\
\hline Carnival Corp. & Apr. 2002 & NYSE - CCL & Services & $\begin{array}{l}\text { False Statements/ } \\
\text { Obstruction }\end{array}$ \\
\hline Ashland Inc. & May 2002 & NYSE - ASH & Energy & $\begin{array}{l}\text { Environmental/Food } \\
\text { Safety }\end{array}$ \\
\hline $\begin{array}{c}\text { ICN } \\
\text { Pharmaceuticals }\end{array}$ & June 2002 & NYSE - ICN & Pharmaceuticals & $\begin{array}{l}\text { Environmental/Food } \\
\text { Safety }\end{array}$ \\
\hline $\begin{array}{l}\text { Koppers } \\
\text { Industries }\end{array}$ & Aug. 2002 & NYSE- KOP & $\begin{array}{l}\text { Chemicals/ } \\
\text { Materials }\end{array}$ & $\begin{array}{l}\text { Environmental/Food } \\
\text { Safety }\end{array}$ \\
\hline OMI Corp. & Jan. 2004 & NYSE - OMM & Transportation & $\begin{array}{l}\text { Environmental/Food } \\
\text { Safety }\end{array}$ \\
\hline Crompton Corp. & Mar. 2004 & NYSE - CK & $\begin{array}{l}\text { Chemicals/ } \\
\text { Materials }\end{array}$ & Antitrust \\
\hline Nash-Finch Co. & Aug. 2004 & $\begin{array}{l}\text { NASDAQ - } \\
\text { NAFC }\end{array}$ & Food & $\begin{array}{l}\text { Environmental/Food } \\
\text { Safety }\end{array}$ \\
\hline Titan Corp. & Mar. 2005 & NYSE - TTN & Defense & FCPA \\
\hline ConAgra Foods & Sep. 2005 & NYSE - CAG & Food & $\begin{array}{l}\text { Environmental/Food } \\
\text { Safety }\end{array}$ \\
\hline Eli Lilly & Dec. 2005 & NYSE - LLY & Pharmaceuticals & Pharma/Drug \\
\hline $\begin{array}{l}\text { Winn-Dixie } \\
\text { Stores }\end{array}$ & Apr. 2006 & $\begin{array}{l}\text { NASDAQ - } \\
\text { WINN }\end{array}$ & Food & $\begin{array}{l}\text { Environmental/Food } \\
\text { Safety }\end{array}$ \\
\hline $\begin{array}{l}\text { Chiquita Brands } \\
\text { Int'l }\end{array}$ & Mar. 2007 & NYSE - CQB & Food & Terrorist Transactions \\
\hline
\end{tabular}




\begin{tabular}{|c|c|c|c|c|}
\hline $\begin{array}{c}\text { Overseas } \\
\text { Shipholding } \\
\text { Group }\end{array}$ & Mar. 2007 & NYSE - OSB & Transportation & $\begin{array}{l}\text { False Statements/ } \\
\text { Obstruction }\end{array}$ \\
\hline ITT Corp. & Mar. 2007 & NYSE - ITT & Defense & Export Violations \\
\hline $\begin{array}{l}\text { Bristol Myers } \\
\text { Squibb }\end{array}$ & June 2007 & NYSE - BMY & Pharmaceuticals & $\begin{array}{l}\text { False Statements/ } \\
\text { Obstruction }\end{array}$ \\
\hline $\begin{array}{l}\text { Honeywell } \\
\text { International }\end{array}$ & Sep. 2007 & NYSE - HON & Manufacturing & $\begin{array}{l}\text { Environmental/Food } \\
\text { Safety }\end{array}$ \\
\hline $\begin{array}{c}\text { Rowan } \\
\text { Companies }\end{array}$ & Oct. 2007 & NYSE - RDC & Energy & $\begin{array}{l}\text { Environmental/Food } \\
\text { Safety }\end{array}$ \\
\hline $\begin{array}{l}\text { Energy Partners, } \\
\text { Ltd. }\end{array}$ & Feb. 2008 & NYSE - EPL & Energy & $\begin{array}{l}\text { Environmental/Food } \\
\text { Safety }\end{array}$ \\
\hline $\begin{array}{l}\text { Archer Daniels } \\
\text { Midland Co. }\end{array}$ & Mar. 2008 & NYSE - ADM & Food & $\begin{array}{l}\text { Environmental/Food } \\
\text { Safety }\end{array}$ \\
\hline $\begin{array}{l}\text { MTS Systems } \\
\text { Corp. }\end{array}$ & Mar. 2008 & $\begin{array}{l}\text { NASDAQ - } \\
\text { MTSC }\end{array}$ & Manufacturing & Export Violations \\
\hline XTO Energy & Apr. 2008 & NYSE - XTO & Energy & $\begin{array}{l}\text { Environmental/Food } \\
\text { Safety }\end{array}$ \\
\hline Cephalon & Sep. 2008 & $\begin{array}{l}\text { NASDAQ - } \\
\text { CHR }\end{array}$ & Pharmaceuticals & Pharma/Drug \\
\hline Herley Industries & May 2008 & $\begin{array}{l}\text { NASDAQ - } \\
\text { HRLY }\end{array}$ & Defense & $\begin{array}{c}\text { False } \\
\text { Statements/Obstruction }\end{array}$ \\
\hline $\begin{array}{l}\text { Exxon Mobil } \\
\text { Corp. }\end{array}$ & Sep. 2008 & NYSE - XOM & Energy & $\begin{array}{l}\text { Environmental/Food } \\
\text { Safety }\end{array}$ \\
\hline Eli Lilly & Jan. 2009 & NYSE - LLY & Pharmaceuticals & Pharma/Drug \\
\hline $\begin{array}{l}\text { Tyson Foods, } \\
\text { Inc. }\end{array}$ & June 2009 & NYSE - TSN & Food & $\begin{array}{l}\text { Environmental/Food } \\
\text { Safety }\end{array}$ \\
\hline Innospec, Inc. & Mar. 2010 & $\begin{array}{l}\text { NASDAQ - } \\
\text { IOSP }\end{array}$ & $\begin{array}{l}\text { Chemicals/ } \\
\text { Materials }\end{array}$ & FCPA \\
\hline Allergan & Sep. 2010 & NYSE - AGN & Pharmaceuticals & Pharma/Drug \\
\hline G\&K Services & Sep. 2010 & $\begin{array}{l}\text { NASDAQ - } \\
\text { GKSR }\end{array}$ & Services & $\begin{array}{l}\text { Environmental/Food } \\
\text { Safety }\end{array}$ \\
\hline Ibiden Co., Ltd & Oct. 2001 & TYO - 4062 & Manufacturing & Antitrust \\
\hline $\begin{array}{l}\text { Morgan Crucible } \\
\text { Co. }\end{array}$ & Nov. 2002 & LSE - MGCR & Manufacturing & $\begin{array}{c}\text { False } \\
\text { Statements/Obstruction }\end{array}$ \\
\hline Rhodia Inc. & June 2004 & $\begin{array}{l}\text { Euronext - } \\
\text { RHA }\end{array}$ & $\begin{array}{l}\text { Chemicals/ } \\
\text { Materials }\end{array}$ & $\begin{array}{l}\text { Environmental/Food } \\
\text { Safety }\end{array}$ \\
\hline $\begin{array}{c}\text { Infineon } \\
\text { Technologies AG }\end{array}$ & Oct. 2004 & FWB - IFX & Manufacturing & Antitrust \\
\hline
\end{tabular}




\begin{tabular}{|c|c|c|c|c|}
\hline Bayer AG & Dec. 2004 & FWB - BAYN & $\begin{array}{l}\text { Chemicals/ } \\
\text { Materials }\end{array}$ & Antitrust \\
\hline $\begin{array}{c}\text { Hynix } \\
\text { Semiconductor }\end{array}$ & May 2005 & KRX - 000660 & Manufacturing & Antitrust \\
\hline $\begin{array}{c}\text { Samsung } \\
\text { Electronics Corp. }\end{array}$ & Oct. 2005 & KRX - 005930 & Manufacturing & Antitrust \\
\hline Elpida Memory & Mar. 2006 & TYO - 6665 & Manufacturing & Antitrust \\
\hline Solvay S.A. & Mar. 2006 & $\begin{array}{l}\text { Euronext - } \\
\text { SOLB }\end{array}$ & $\begin{array}{l}\text { Chemicals/ } \\
\text { Materials }\end{array}$ & Antitrust \\
\hline $\begin{array}{c}\text { Bennett } \\
\text { Environmental } \\
\text { Inc. }\end{array}$ & Jul. 2007 & TSE - BEI & Services & Fraud \\
\hline Air France/KLM & Jul. 2007 & Euronext - AF & Transportation & Antitrust \\
\hline British Airways & Aug. 2007 & LSE - BAY & Transportation & Antitrust \\
\hline Qantas Airways & Nov. 2007 & ASX - QAN & Transportation & Antitrust \\
\hline $\begin{array}{c}\text { Japan Airlines } \\
\text { International }\end{array}$ & May 2008 & TYO - 9205 & Transportation & Antitrust \\
\hline $\begin{array}{l}\text { Cathay Pacific } \\
\text { Airways Ltd. }\end{array}$ & Aug. 2008 & SEHK - 0293 & Transportation & Antitrust \\
\hline Siemens AG & Dec. 2008 & FWB - SIE & Manufacturing & FCPA \\
\hline Sharp Corp. & Dec. 2008 & TYO - 6753 & Manufacturing & Antitrust \\
\hline $\begin{array}{l}\text { LG Display Co., } \\
\text { Ltd. }\end{array}$ & Dec. 2008 & KRX - 034220 & Manufacturing & Antitrust \\
\hline $\begin{array}{c}\text { BAE Systems } \\
\text { PLC }\end{array}$ & Mar. 2010 & LSE - BA & Defense & FCPA \\
\hline Panasonic Corp. & Nov. 2010 & TYO - 6752 & Manufacturing & Antitrust \\
\hline
\end{tabular}


Appendix B. Companies Convicted 2001 - 2010, Plea Details and Company Fate

\begin{tabular}{|c|c|c|c|c|c|c|}
\hline Company & $\begin{array}{c}\text { Compliance } \\
\text { Plan }\end{array}$ & Monitor & $\begin{array}{c}\text { Total } \\
\text { Penalty }\end{array}$ & Other & Fate & Time \\
\hline Utilicorp United & UNK & UNK & $1,000,000$ & & Failed & $>3$ years \\
\hline Kaydon Corp. & UNK & UNK & $1,000,000$ & & Active & N/A \\
\hline Sara Lee Corp. & UNK & UNK & $3,200,000$ & & Active & N/A \\
\hline $\begin{array}{l}\text { MacDermid, } \\
\text { Inc. }\end{array}$ & UNK & UNK & $2,003,000$ & & Merged & $>3$ years \\
\hline $\begin{array}{c}\text { ICN } \\
\text { Pharmaceuticals }\end{array}$ & UNK & UNK & $5,600,000$ & & Merged & $>3$ years \\
\hline Carnival Corp. & $\mathrm{Y}$ & $\mathrm{N}$ & $18,000,000$ & & Active & N/A \\
\hline Ashland Inc. & UNK & UNK & $9,150,000$ & & Active & N/A \\
\hline $\begin{array}{c}\text { ICN } \\
\text { Pharmaceuticals }\end{array}$ & UNK & UNK & 40,000 & & Merged & $>3$ years \\
\hline $\begin{array}{l}\text { Koppers } \\
\text { Industries }\end{array}$ & $\mathrm{Y}$ & UNK & $3,000,000$ & & Active & N/A \\
\hline OMI Corp. & UNK & UNK & $4,200,000$ & & Merged & $>3$ years \\
\hline Crompton Corp. & $\mathrm{N}$ & $\mathrm{N}$ & $50,000,000$ & & Merged & $>1$ year \\
\hline Nash-Finch Co. & UNK & UNK & 400,000 & & Active & N/A \\
\hline Titan Corp. & UNK & UNK & $28,500,000$ & & Merged & $<1$ year \\
\hline ConAgra Foods & UNK & UNK & 250,000 & & Active & N/A \\
\hline Eli Lilly & Y & $\mathrm{N}$ & $30,000,000$ & Coop. & Active & N/A \\
\hline $\begin{array}{l}\text { Winn-Dixie } \\
\text { Stores }\end{array}$ & UNK & UNK & 200,000 & & Failed & $>3$ years \\
\hline $\begin{array}{c}\text { Chiquita Brands } \\
\text { Int'l }\end{array}$ & $\mathrm{Y}$ & $\mathrm{N}$ & $25,000,000$ & $\begin{array}{l}\text { PW, } \\
\text { Coop. }\end{array}$ & Active & N/A \\
\hline $\begin{array}{c}\text { Overseas } \\
\text { Shipholding } \\
\text { Group }\end{array}$ & Y & $\mathrm{Y}$ & $37,000,000$ & Coop. & Active & N/A \\
\hline ITT Corp. & $\mathrm{N}$ & $\mathrm{N}$ & $30,000,000$ & & Active & N/A \\
\hline $\begin{array}{l}\text { Bristol Myers } \\
\text { Squibb }\end{array}$ & $\mathrm{N}$ & $\mathrm{N}$ & $1,000,000$ & Coop. & Active & N/A \\
\hline $\begin{array}{l}\text { Honeywell } \\
\text { International }\end{array}$ & $\mathrm{Y}$ & $\mathrm{N}$ & $10,000,000$ & & Active & N/A \\
\hline $\begin{array}{c}\text { Rowan } \\
\text { Companies }\end{array}$ & UNK & UNK & $8,000,000$ & & Active & N/A \\
\hline
\end{tabular}




\begin{tabular}{|c|c|c|c|c|c|c|}
\hline $\begin{array}{c}\text { Energy } \\
\text { Partners, Ltd. }\end{array}$ & $\mathrm{N}$ & $\mathrm{N}$ & 100,000 & Coop. & Failed & $>1$ year \\
\hline $\begin{array}{l}\text { Archer Daniels } \\
\text { Midland Co. }\end{array}$ & $\mathrm{N}$ & $\mathrm{N}$ & 100,000 & & Active & N/A \\
\hline $\begin{array}{c}\text { MTS Systems } \\
\text { Corp. }\end{array}$ & $\mathrm{N}$ & $\mathrm{N}$ & 400,000 & & Active & N/A \\
\hline XTO Energy & $\mathrm{Y}$ & $\mathrm{N}$ & 20,000 & & Merged & $>1$ year \\
\hline Cephalon & $\mathrm{N}$ & $\mathrm{N}$ & $425,000,000$ & & Merged & $>1$ year \\
\hline $\begin{array}{l}\text { Herley } \\
\text { Industries }\end{array}$ & $\mathrm{N}$ & $\mathrm{N}$ & $6,000,000$ & & Merged & $>1$ year \\
\hline $\begin{array}{c}\text { Exxon Mobil } \\
\text { Corp. }\end{array}$ & $\mathrm{Y}$ & $\mathrm{N}$ & 600,000 & & Active & N/A \\
\hline Eli Lilly & $\mathrm{Y}$ & UNK & $1,615,000,000$ & & Active & N/A \\
\hline $\begin{array}{l}\text { Tyson Foods, } \\
\text { Inc. }\end{array}$ & $\mathrm{N}$ & $\mathrm{N}$ & 500,000 & & Active & N/A \\
\hline Innospec, Inc. & $\mathrm{Y}$ & $\mathrm{Y}$ & $14,100,000$ & & Active & N/A \\
\hline Allergan & $\mathrm{Y}$ & $\mathrm{N}$ & $650,000,000$ & & Active & N/A \\
\hline G\&K Services & $\mathrm{N}$ & $\mathrm{N}$ & 450,000 & & Active & N/A \\
\hline Ibiden Co., Ltd & UNK & UNK & $3,600,000$ & & Active & N/A \\
\hline $\begin{array}{c}\text { Morgan } \\
\text { Crucible Co. }\end{array}$ & $\mathrm{N}$ & $\mathrm{N}$ & $1,000,000$ & Coop. & Active & N/A \\
\hline Rhodia Inc. & $\mathrm{N}$ & $\mathrm{N}$ & $18,000,000$ & $\begin{array}{l}\text { Comm. } \\
\text { Service }\end{array}$ & Merged & $>3$ years \\
\hline $\begin{array}{c}\text { Infineon } \\
\text { Technologies } \\
\text { AG }\end{array}$ & $\mathrm{N}$ & $\mathrm{N}$ & $160,000,000$ & Coop. & Active & N/A \\
\hline Bayer AG & $\mathrm{N}$ & $\mathrm{N}$ & $66,000,000$ & & Active & N/A \\
\hline $\begin{array}{c}\text { Hynix } \\
\text { Semiconductor }\end{array}$ & $\mathrm{N}$ & $\mathrm{N}$ & $185,000,000$ & Coop. & Merged & $>3$ years \\
\hline $\begin{array}{l}\text { Samsung } \\
\text { Electronics } \\
\text { Corp. }\end{array}$ & $\mathrm{N}$ & $\mathrm{N}$ & $300,000,000$ & Coop. & Active & N/A \\
\hline Elpida Memory & $\mathrm{N}$ & $\mathrm{N}$ & $84,000,000$ & Coop. & Failed & $>3$ years \\
\hline Solvay S.A. & $\mathrm{N}$ & $\mathrm{N}$ & $40,870,000$ & & Active & N/A \\
\hline
\end{tabular}




\begin{tabular}{|c|c|c|c|c|c|c|}
\hline $\begin{array}{c}\text { Bennett } \\
\text { Environmental } \\
\text { Inc. }\end{array}$ & UNK & UNK & $2,662,000$ & & Active & N/A \\
\hline $\begin{array}{c}\text { Air } \\
\text { France/KLM }\end{array}$ & $\mathrm{N}$ & $\mathrm{N}$ & $350,000,000$ & & Active & N/A \\
\hline British Airways & $\mathrm{N}$ & $\mathrm{N}$ & $300,000,000$ & Coop. & Merged & $>3$ years \\
\hline Qantas Airways & $\mathrm{N}$ & $\mathrm{N}$ & $61,000,000$ & & Active & N/A \\
\hline $\begin{array}{l}\text { Japan Airlines } \\
\text { International }\end{array}$ & $\mathrm{N}$ & $\mathrm{N}$ & $110,000,000$ & Coop. & Failed & $>1$ year \\
\hline $\begin{array}{l}\text { Cathay Pacific } \\
\text { Airways Ltd. }\end{array}$ & $\mathrm{N}$ & $\mathrm{N}$ & $60,000,000$ & Coop. & Active & N/A \\
\hline Siemens AG & Y & $\mathrm{Y}$ & $448,500,000$ & Coop. & Active & N/A \\
\hline Sharp Corp. & $\mathrm{N}$ & $\mathrm{N}$ & $120,000,000$ & Coop. & Active & N/A \\
\hline $\begin{array}{l}\text { LG Display Co., } \\
\text { Ltd. }\end{array}$ & $\mathrm{N}$ & $\mathrm{N}$ & $400,000,000$ & Coop. & Active & N/A \\
\hline $\begin{array}{l}\text { BAE Systems } \\
\text { PLC }\end{array}$ & $\mathrm{Y}$ & $\mathrm{Y}$ & $400,000,000$ & Coop. & Active & N/A \\
\hline Panasonic Corp. & $\mathrm{N}$ & $\mathrm{N}$ & $49,100,000$ & Coop. & Active & N/A \\
\hline
\end{tabular}

